\title{
Hominoids from Neuhausen and other Bohnerz localities, Swabian Alb, Germany: evidence for a high diversity of apes in the Late Miocene of Germany
}

\author{
Homínidos de Neuhausen y otras localidades de Bohnerz, Jura de \\ Suabia, Alemania. Evidencias de una gran diversidad de primates \\ en el Mioceno Superior de Alemania
}

\author{
M. Pickford ${ }^{1}$
}

\begin{abstract}
Three hominoid upper teeth collected prior to 1837 from late Miocene Bohnerz near Neuhausen, Swabian Alb (Germany) are described in detail for the first time and are attributed to Anoiapithecus brevirostris and Dryopithecus crusafonti (which shares morphological features with Udabnopithecus garedziensis). Their discovery locus is not far from several other Bohnerz sites which have yielded dryopithecine teeth (Salmendingen, Melchingen, Trochtelfingen, Ebingen) of similar age (MN 7/8 - MN 9). These are the first ante-molar dryopithecine teeth recognised in Germany, and as such provide evidence concerning the affinities of the hominoids from the Swabian Alb. Previously described ape dento-gnathic samples from Germany comprised only molars, which are less diagnostic than the anterior dentition, a fact that has given rise to an extended debate about the affinities of these teeth. Detailed comparisons between the German hominoid fossils and those from Austria, Slovakia, Hungary, Georgia, Turkey and Spain, indicates that there may be five species of hominoids in the ensemble of Swabian Alb deposits (Dryopithecus fontani, Neopithecus brancoi, possibly Griphopithecus sp., Anoiapithecus brevirostris, Udabnopithecus garedziensis (which could be a senior synonym of Dryopithecus crusafonti) and Hispanopithecus laietanus).
\end{abstract}

Key words: Hominoidea, Dryopithecinae, Apes, Late Miocene, Swabian Alb, Bohnerz, Neuhausen, Germany

\section{RESUMEN}

En este trabajo se describen en detalle por primera vez tres dientes de homínidos superiores recogidos antes de 1837 a partir de finales del Mioceno Bohnerz cerca de Neuhausen, Jura de Suabia (Alemania) y se atribuyen a Anoiapithecus brevirostris y Dryopithecus crusafonti (que comparte características morfológicas con Udabnopithecus garedziensis). Su lugar de descubrimiento no está lejos de muchos otros sitios Bohnerz que han proporcionado dientes de dryopithecine (Salmendingen, Melchingen, Trochtelfingen, Ebingen) de la misma edad (MN 7 / 8MN 9). Estos son los primeros dientes antemolares de dryopithecines reconocidos en Alemania, y como tales, proporcionan evidencias sobre las afinidades de los homínidos del Jura de Suabia.

Las muestras dentognáticas de simios de Alemania previamente descritas, se componen únicamente de molares, que son menos diagnósticos de la dentición anterior, un hecho que ha dado lugar a un amplio debate acerca de las afinidades de estos dientes. La comparación detallada entre los homínidos fósiles de Alemania y los de Austria, Eslovaquia, Hungría, Georgia, Turquía y España, indica que puede haber cinco especies de homínidos en el conjunto de depósitos del Jura de Suabia (Dryopithecus Fontani, Neopithecus brancoi, posiblemente Griphopithecus sp., Anoiapithecus brevirostris, Udabnopithecus garedziensis (que podría ser un sinónimo de Dryopithecus crusafonti) y laietanus Hispanopithecus laietanus).

Palabras clave: Hominoidea, Dryopithecinae, simios, Mioceno Superior, Jura de Suabia, Bohnerz,

\footnotetext{
1 Collège de France, Paris, France, and UMR 7207 (CR2P) du CNRS, 8, rue Buffon, 75005, Paris, France, Email: pickford @mnhn.fr.
} 


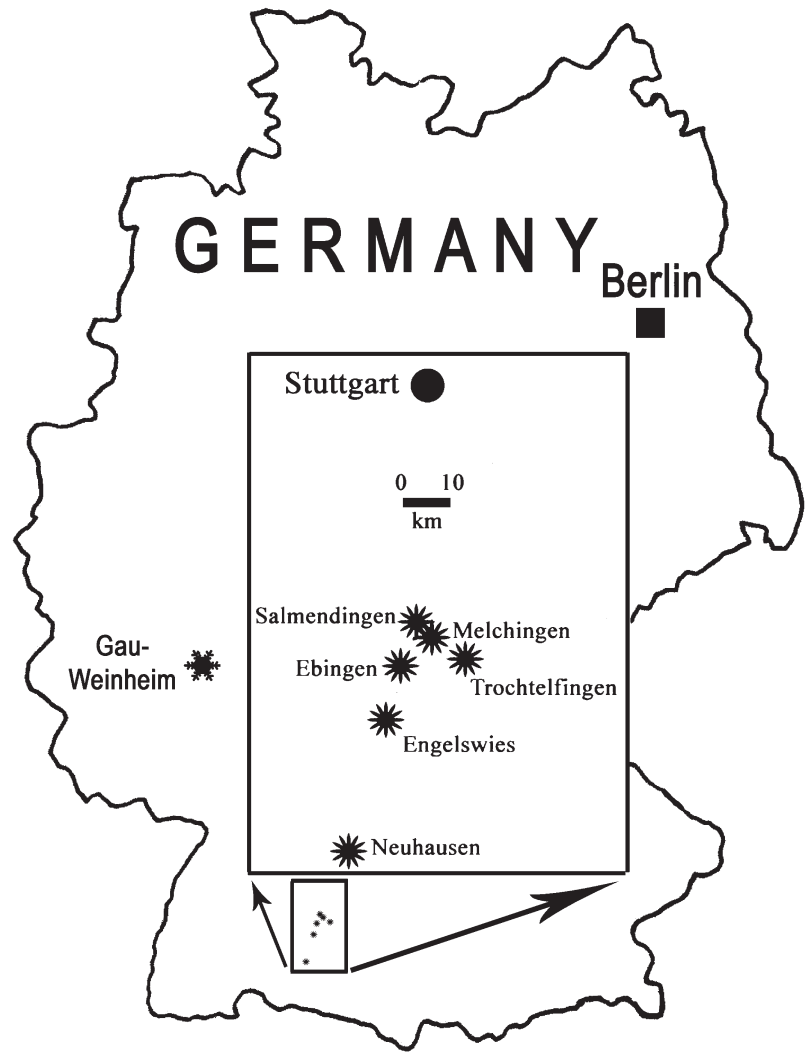

Fig. 1.-Location of the main areas in the Swabian Alb, southern Germany, where the Bohnerz yielded hominoid fossils (stars) during the early part of the $19^{\text {th }}$ Century. Also shown is the dryopithecine site of Wissberg (Gau-Weinheim), Rhine Graben, the most septentrional Miocene hominoid site in Europe.

\section{Introduction}

In 1837, Herr Bergmeister Zobel (Ludwigsthal) donated a collection of fossils from Neuhausen (Fig. 1), which had been in his possession for an unknown period of time, to the State Museum of Natural History at Stuttgart (SMNS). The fossils featured in the 1839 publication by G.F. Jäger, who prepared a detailed illustrated catalogue of the fossil samples housed in the museum. Most, if not all, of the fossils from Neuhausen listed by G.F. Jäger (1839) are still preserved in the SMNS, and can be positively identified thanks to the excellent quality of the illustrations published by him (Jäger, 1839, Pl. X) and to his hand-written labels which still accompany the fossils (Fig. 2).

The Neuhausen fossils come from three geological settings: older Eocene (ob. Ludium = Late Priabonian) fissure fillings rich in the remains of palaeotheres in which the teeth are red to orange in colour, with pale yellowish roots; a younger suite of Miocene fossils; and even younger Pleistocene fossils and even Recent bones from the Bohnerz, a superficial karstrelated deposit rich in small ironstone nodules that look like beans, hence the name Bohnerz (Bean ore).

Jäger's (1839) publication is essentially an extensive catalogue providing brief descriptions of the fossils and listing their localities and superficial preservation characteristics, rather than a detailed palaeontological treatise. He identified the fossils to the best of his knowledge, and on several occasions he admits in the text that he was at a loss to determine the species to which some of the specimens belong. As was the custom at the time, the fossils were illustrated in plates at the end of the publication, with minimalist legends providing only the locality or stratum, and the taxonomic identification. For further details one needs to cross-check back to the text, where the body part determination of the specimens is provided along with a taxonomic assignment and some details of the provenience.

The three dryopithecine teeth from Neuhausen allow the proposal of solutions to the long and intricate debate concerning the Miocene fossil apes from the Swabian Alb, a debate that was largely fuelled by the fact that previously known samples consisted only of isolated molars.

\section{Associated fauna and biochronology}

Examination of the Bohnerz fossils in the Zobel collection from Neuhausen stored at the SMNS yields the following faunal list (Table 1).

Although there is necessarily some doubt about the association of the Neuhausen fossils (they were extracted during iron mining of the Bohnerz), this assemblage, despite the relatively low diversity, is evidently of Vallesian affinities (MN 9) (Heizmann, pers. comm.) although correlation with MN 10 cannot be ruled out. The likely age of the dryopithecine remains from Neuhausen is post-Hipparion datum, thus about $10 \pm 1 \mathrm{Ma}$, whereas it is evident that some of the German hominoid fossils, such as those from Salmendingen may be somewhat older, MN 7/8 rather than MN 9-10.

\section{Hominoid fossils from the Swabian Alb}

The Swabian Alb have yielded fossil hominoid teeth from a variety of deposits including fissure 


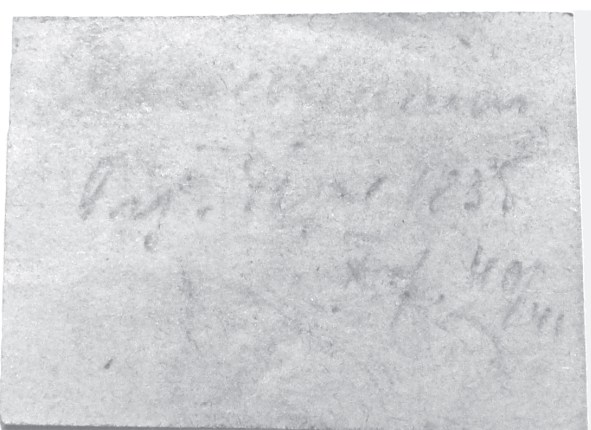

A

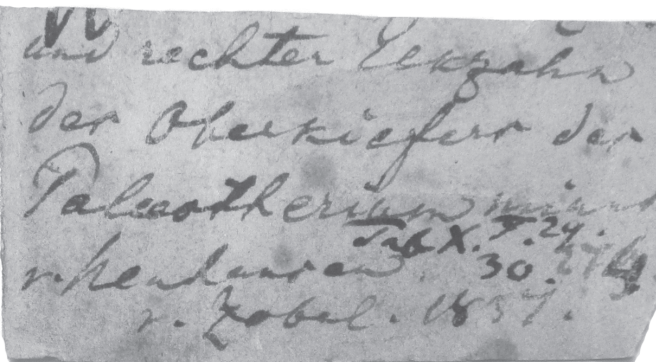

$\mathrm{C}$

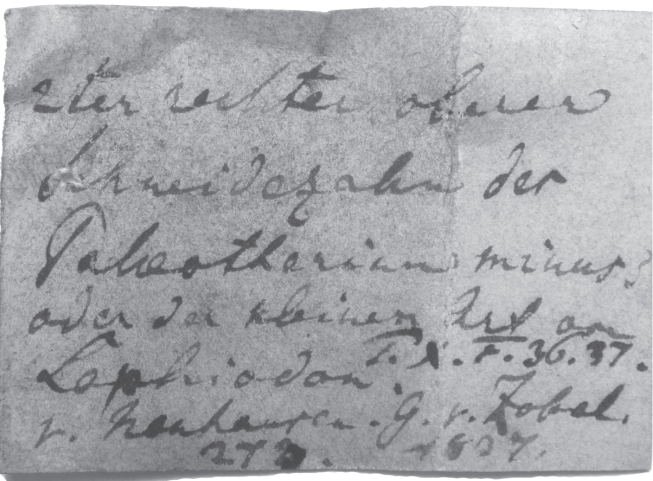

B

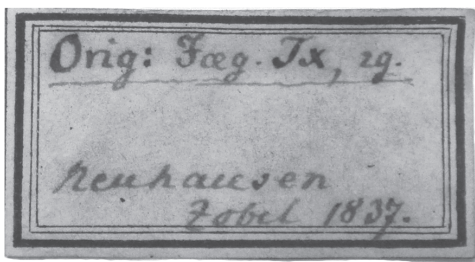

D

Fig. 2.-Original labels accompanying the Neuhausen hominoid fossils. (A) Much faded, label written in pencil concerning the P3/ from Neuhausen reads "Chalicotherium Orig. Jäger. 1835 X/ 40/41". (B) Label for the upper central incisor from Neuhausen reads "2ter rechter oberer Schneidezahn des Palaeotherium minus? oder der kleinen Art von Lophiodon v. Neuhausen. G. v. Zobel. 273, 1837. T. x. F. 36. 37." (C-D) Labels found with the upper canine from Neuhausen read (C) "und rechter Eckzahn der Oberkiefer der Palaeotherium minor v. Neuhausen. 274. v. Zobel 1837. Tab X. F. 29. 30." and (D) "Orig. Jaeg. Tx, 29. Neuhausen Zobel 1837". These labels effectively remove any residual doubt that the specimens are the same as those described by Jäger (1839).

\section{Table 1.-Faunal list of Late Miocene mammals from Neuhausen, Swabian Alb, Germany}

\section{Carnivora}

Ursavus depereti

SMNS 43485 left lower canine

Chalicotheriidae

Chalicotherium sp.

SMNS 47447 (282) upper molar protocone

Rhinocerotidae Indet. sp.

Equidae

Suidae

Hipparion sp.

Propotamochoerus palaeochoerus

SMNS 47451 (280) anterior lobe right $\mathrm{m} / 3$

Bovidae

Miotragocerus suevicus

Antilope jaegeri

Cervidae

Cervus sp.
SMNS 43484 left m/1

SMNS 47446 (281) upper molar ectoloph

SMNS 47448 cheek tooth enamel

SMNS 47449 (63) right $\mathrm{p} / 2$

SMNS 47454 left $\mathrm{P} 4 /$, fragment of right $\mathrm{m} / 3$

SMNS 47450 (286) left P3/

SMNS 47452 (283) left P3/

SMNS 45102 right $\mathrm{m} / 3$

SMNS 47453 (267) left M1/

SMNS 44216a left P3/

SMNS 44216b right M1/

The names are given as they appear on the museum labels and some of them (e.g. Cervus sp.) probably need revision. 
fillings (Ebingen, Melchingen, Salmendingen, Trochtelfingen) and marls associated with travertine (Engelswies).

The fissure fillings of the Swabian Alb have long been known to contain abundant fossils of Eocene, Miocene and more recent age. The Bohnerz, which infills superficial karst fissures, was actively mined during the early 1800's for its iron content. The mining was done by hand, the miners following the ore-rich fissures, with the result that most fissure fills were completely cleaned out, and there remains little possibility for further palaeontological collections except in the few fissures that were missed by the miners. On the plus side, because the mining was done by hand, fossils observed by the miners were often collected and handed over to the mine overseers or to town or village mayors or to local schools, usually as curiosities. Some of these fossils were later presented to the state museums which had been created by that time. By this means the Stuttgart Naturkunde Museum obtained interesting fossil samples from a number of Swabian Alb deposits, among which that of Neuhausen is the subject of this paper.

The Neuhausen and other fissure complexes were already known in the 1830's for their rich palaeothere faunas, and it was possibly because of this that Jäger $(1839,1850)$ was prone to identify fossils that he was doubtful about, as perissodactyls. The upper P3/, here attributed to a dryopithecine, was identified by him as a lower tooth of a chalicothere, whilst the upper central incisor and the upper canine were identified by him as Palaeotherium minus. Recall that, at this epoch, mammalian palaeontology in Europe was still in its infancy, and many comparisons had to be made with published descriptions and images, with researchers often isolated from like-minded colleagues, and with little in the way of extant comparative material. For 170 years, these interesting dryopithecine teeth remained incorrectly labelled as perissodactyls. In retrospect, even the illustrations by Jäger (1839) are sufficiently clear to show that the specimens are not perissodactyls. The illustrations of the incisor are, in particular, clearly those of a hominoid primate (presence of lingual pillar) and not of a palaeothere (lingual surface deeply concave).

The genusDryopithecus was erected by Lartet (1856) on the basis of a mandible from St Gaudens, France (MN8). The Neuhausen fossils were collected at least 19 years earlierthe year that they were donated to the SMNS by Herr Zobel. They may well have been in his custody for several years before that. These hominoid specimens thus have the potential of being the first fossil apes collected in Europe, if not in the world, not counting the Salmendingen tooth (SMNS 43460) which was published four years earlier (Jäger, 1835) which has alternatively been attributed to Anapithecus hernyaki by Begun (2002) or to Dryopithecus by Remane (1921) and Abel (1931) or as incertae sedis by Andrews et al. (1996). It is in fact a deciduous tooth, as shown by the presence of an oblique cristid entering the mesial fovea from the apex of the protoconid and subdividing it into two halves (Hürzeler, 1951, fig. 3). The discovery of the Neuhausen fossil apes predates that of the first Siwalik (Indian Subcontinent) hominoids by a substantial margin (Kelley, 2002).

\section{Material and Methods}

The fossils described here are curated at the Staatliches Museum für Naturkunde in Stuttgart (SMNS), the Bayerische Staatssammlung für Paläontologie und Geologie und GeobioCenter der Ludwig-Maximilians- Universität, München (BSPG), and the Geologisches und Palaeontologisches Institut Tübingen (GPIT).

Measurements are to the nearest tenth of a mm. In the accompanying bivariate plots, it should be noted that authors do not always present measurements of upper incisors in the same way. Thus Moyà-Solà and Köhler (1995) and Moyà-Solà et al. (2004) provide length $\mathrm{x}$ breadth measurements for upper central incisors of D. laietanus from Can Llobateres, and Pierolapithecus catalaunicus from Els Hostalets de Pierola, but these correspond to the labio-lingual breadth and mesio-distal length measurements respectively of other authors (Begun, 1992a; Ribot et al., 1996). If the Can Llobateres and Els Hostalets de Pierola data are plotted as published, without transposing the values, the specimens appear broader relative to length than is the case.

"Hostalets de Pierola" is the toponym where the locus typicus of Pierolapithecus catalaunicus is situated. It is employed in a broad sense to refer to groups of localities for the classical sites that are customarily termed "Hostalets Inferior" (Lower Hostalets) or "Hostalets Superior" (Upper Hostalets). In order to avoid misunderstandings with these other localities, it is pointed out that "Barranc de Can Vila 1" (BCV1) is the type locality of $P$. catalaunicus, (also referred to as the "Abocador de Can Mata", which is the name given to the local stratigraphic series where BCV1 occurs).

Abbreviations in the text are as follows:- I1/ - upper central incisor, C1/upper canine, $\mathrm{P} 3 /$ - upper third premolar, $\mathrm{M}$ - upper molar, $\mathrm{m} / 3$ lower third molar. Institutional abbreviations are:BSPG - Bayerische Staatssammlung für Paläontologie und Geo-Biologie, GPIT MA - Geologisches und Palaeontologisches Institut Tübingen, Mammalia, IPS - Institut Català de Paleontologia, Universitat Autònoma de Barcelona (formerly Institut de Paleontologia M. Crusafont, Sabadell), RUD - Rudabánya, SMNSStaatliches Museum für Naturkunde in Stuttgart. 


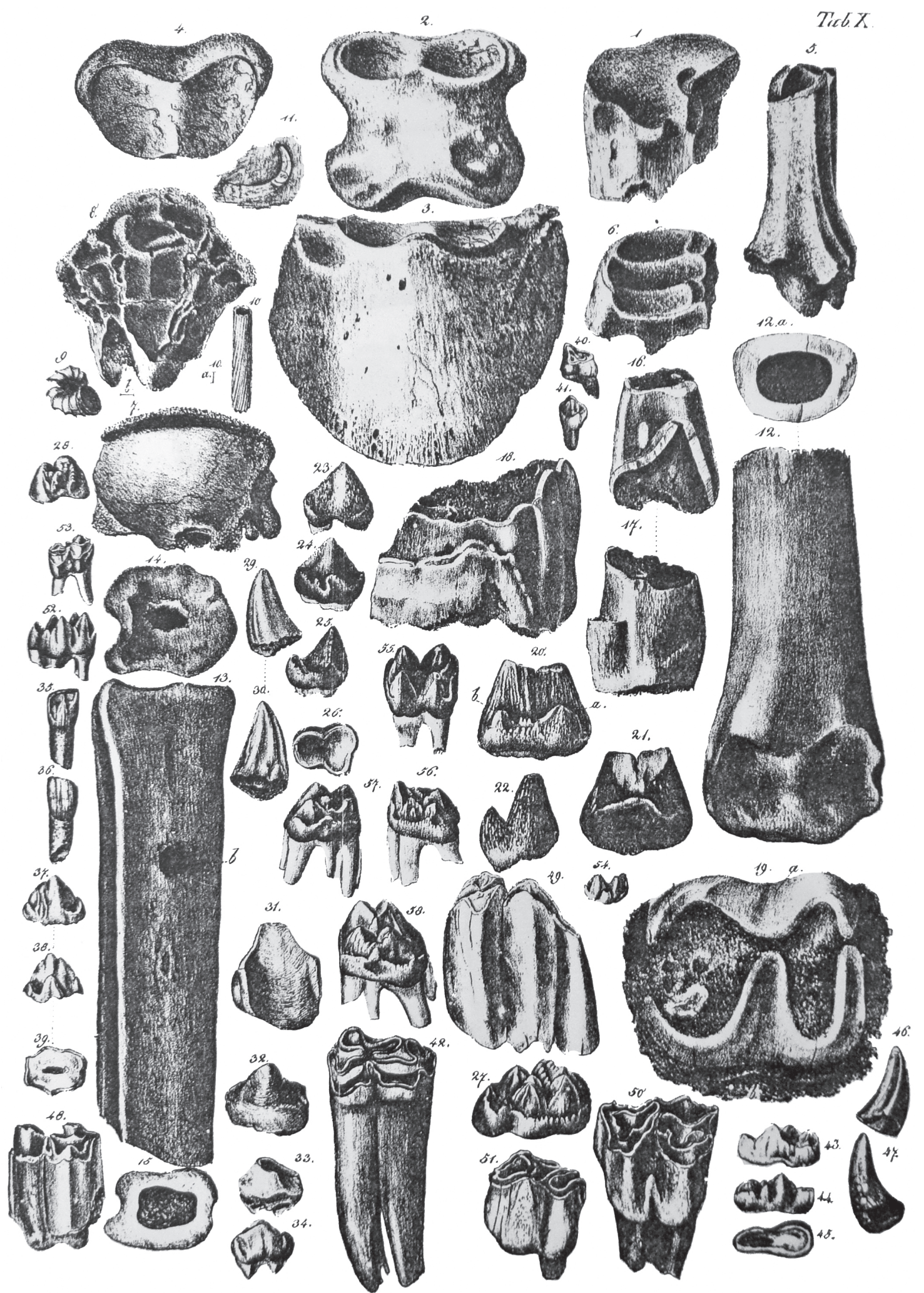

Fig. 3.-Fossils from the Bohnerz, Swabian Alb, Germany - reproduction of Plate X of Jäger, 1839. Most of the Neuhausen fossils figure on this plate, along with fossils from other Miocene localities. The dryopithecine teeth are figures 29-30, 35-36 and 40-41. There is no scale on the figure but the figures on the original plate are approximately natural size. 


\section{Archival and historical background}

Among the fossils in the Zobel collection from Neuhausen there are three teeth that attract attention (Table 1) (Figs 2-6). All three were attributed to perissodactyls by Jäger (1839) who was evidently influenced by the fact that the area is rich in the remains of palaeotheres. SMNS 43650 (= 284 in Jäger) (Fig. 2A) was identified as a lower tooth of Chalicotherium ? in the figure legend (Jäger, 1839, p. 73, Pl. X, Fig. 40 \& 41) but the text indicates that the author was doubtful about its determination - it is an upper left P3/ of a dryopithecine. SMNS 47444 (= 273 in Jäger) (Fig. 2B) was identified as a right upper I2/ of Palaeotherium minus (Jäger, 1839, p.73, Pl. X, Fig. 35 \& 36) it is a right I1/ of a dryopithecine. SMNS 47445 (= Jäger 274) (Fig. 2C, 2D) was identified as a right upper canine of Palaeotherium (minus) (Jäger, 1839, p. 73, Pl. X, Fig. 29 \& 30) - it is a right upper canine of a dryopithecine.

The other vertebrate material from Neuhausen (Fig. 3) listed by Jäger (1839) which the author was able to study, reveals that the area yielded fossils from strata of diverse ages. Determining the faunal associations under such circumstances is difficult, but the preservation characters provide useful information. It is easy to exclude the Eocene fossils because all the teeth of this age possess red to orange enamel with yellow roots. The Recent and Pleistocene fossils possess whitish enamel and roots, whereas fossil teeth in the Miocene assemblage possess enamel with a bluish tinge with manganese streaks in tiny fissures, and the roots tend to be black or dark brown. A few Miocene fossils are reddish brown.

\section{Systematic descriptions}

\section{Order: Primates Linnaeus, 1758}

Superfamily Hominoidea Gray, 1825

Subfamily Dryopithecinae Gregory \& Hellman, 1939

There is currently little or no consensus about suprageneric groupings of Hominoidea (Pickford et al., 2010). In this paper the terms "dryopithecine", "sivapithecine", "afropithecine" (with lower case initial letters) are used as a short-hand, somewhat informal way, to encompass European large fossil apes, Asian large fossil apes, and African fossil thick-enamelled apes respectively, but it is pointed out that few palaeoanthropologists agree as to the contents of these groups. The terms "kenyapithecine" and "proconsulid" are also informal when written with lower case initial letters and refer to the genera Kenyapithecus, Nacholapithecus and Equatorius for the former, and the genera $P$ roconsul, Ugandapithecus and close relatives for the latter. The term Hominidae is here used in its narrow sense, referring to hominoids which show bipedal locomotor adaptations resembling or approaching those shown by humans and their immediate precursors (australopithecines and Orrorin) (and thus excluding Oreopithecus).

\section{Description}

SMNS 47444, a right I1/ (Fig. 4, 5) is in light wear. In lingual view, the central pillar is massive and extends from the
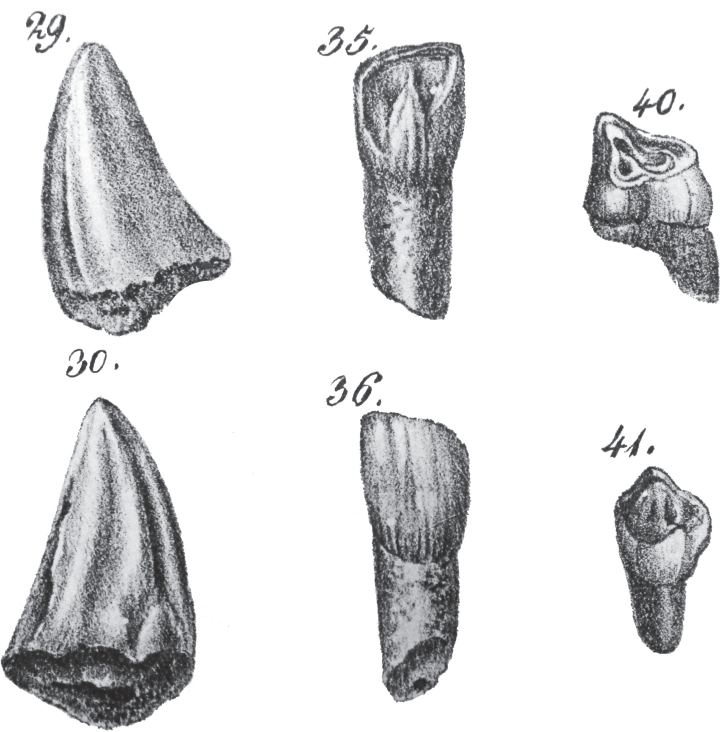

Fig. 4.-Three dryopithecine teeth from Neuhausen, figured by Jäger (1839, PI. X). Images enlarged to show the great detail that the artist was able to convey in the images, including the manganese filled streaks in the incisor (Fig. 35-36), the wear facet down the distal ridge of the canine (Fig. 29-30) (wavy vertical dark tones at left of image), as well as the presence of three foveae on the P3/ (Fig. 40-41). (29 - buccal, 30 - lingual, 35 lingual, 36 - labial, 40 - oblique mesial view, 41 - oblique lingual view) (no scale on original plate).

cervix apically for $8 \mathrm{~mm}$, terminating about $2.5 \mathrm{~mm}$ beneath the cutting edge of the tooth. There is a low crest that extends apically from the top of pillar as far as the apical wear facet. The mesial marginal crest on the lingual aspect of the crown is well developed apically and is separated from the central pillar basally by a narrow groove. Between the marginal crest and the central pillar, there is a concavity in which there is a low vertical enamel fold. The distal marginal crest is weaker than the mesial one, but it too is separated basally from the lingual pillar by a narrow groove. In the fovea between the central pillar and the distal marginal crests there is a low, obliquely angled enamel wrinkle. The lingual surface of the central pillar is lightly wrinkled vertically. Wear facets on the lingual surface consist of clear, planar wear surfaces on the mesial marginal crest, and the apex of the central pillar.

In labial view the surface of the incisor crown is overall convex, but with a shallow vertical concavity towards the mesial third, extending from near cervix as far as the apex. This concavity is reflected in the apical wear facet which is subdivided into two parts, a small mesial part and a more extensive distal part. The distal margin of the crown is not greatly expanded distally, such that the tooth is only slightly longer at mid-crown height than it is apically and cervically. There are low vertical wrinkles on the distal part of the crown. Perikymata are clearly visible on the labial surface of the tooth extending onto the mesial, distal and lingual surfaces.

In mesial view the interstitial wear facet caused by abrasion against its opposite number, is near the apex, and is quite flat, as is usually the case in hominoid central incisors. The orientation of this interstitial facet reveals that the two incisors were not highly 


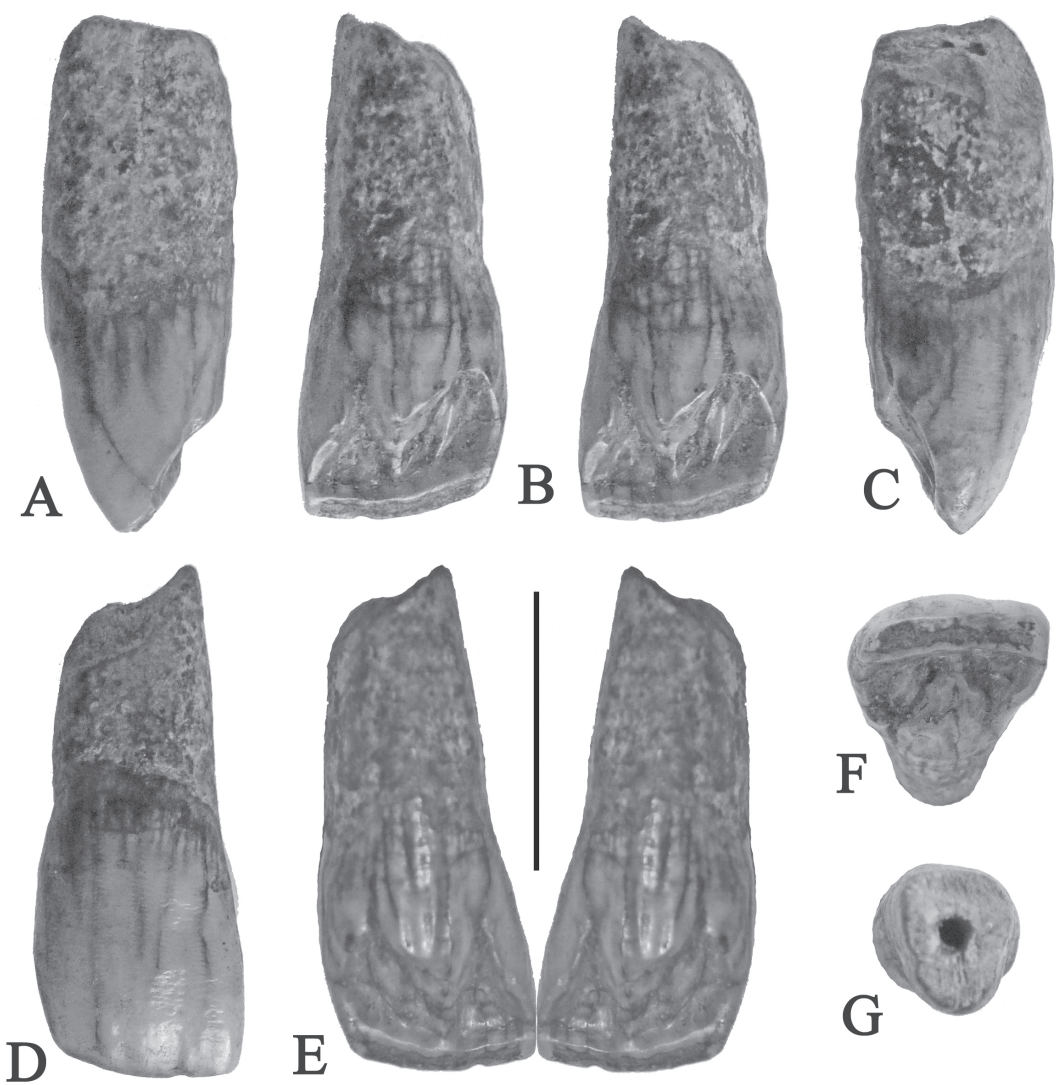

Fig. 5.-SMNS 47444, Dryopithecine right I1/, Neuhausen, Late Miocene (Vallesian) Bohnerzgruben, Swabian Alb, Germany. A) mesial, B) stereo lingual, C) distal, D) labial, E) reconstructed central incisor row, lingual, F) occlusal, and G) radicular views, (scale: $10 \mathrm{~mm}$ ).
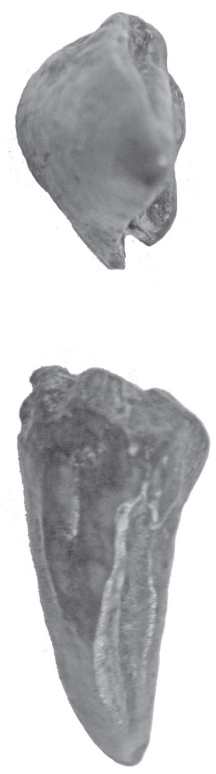

A

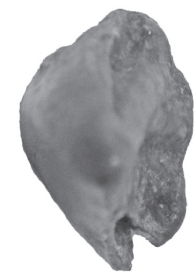

B
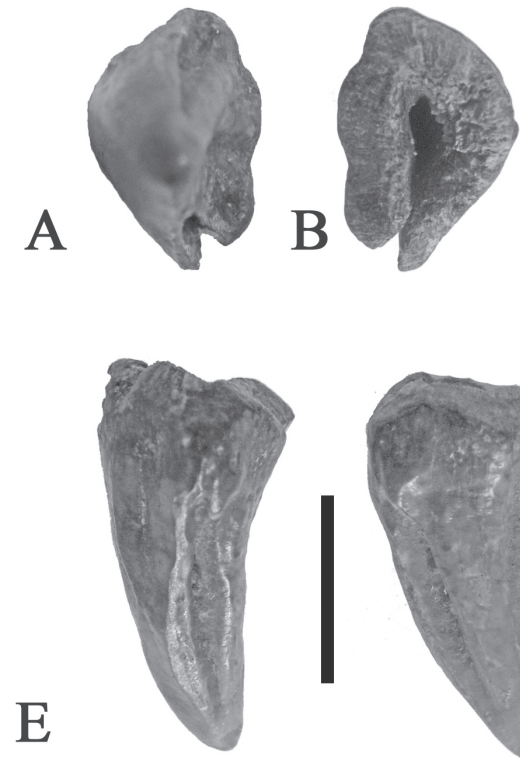
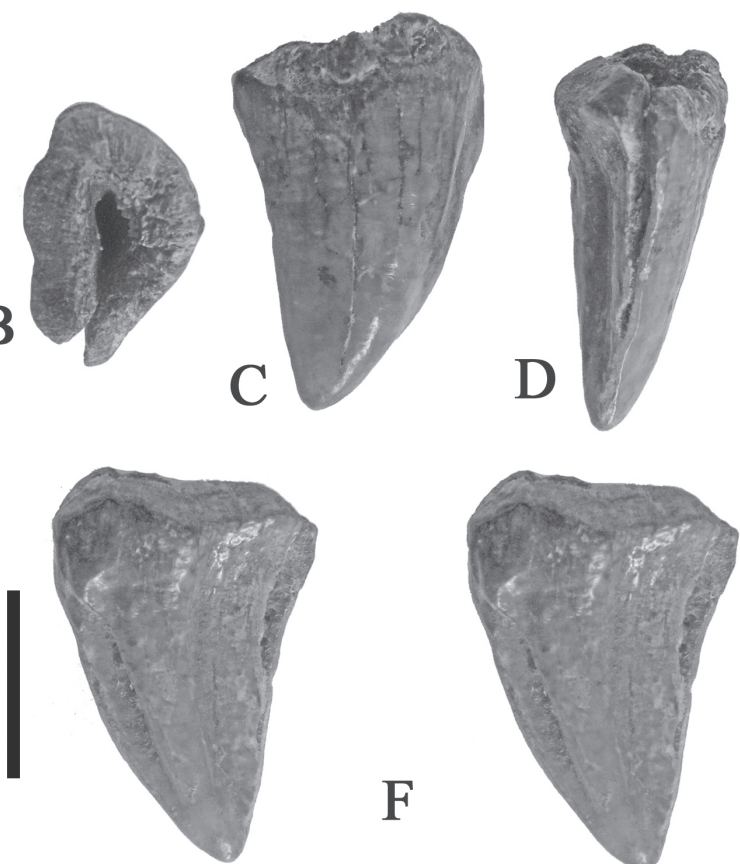

$\mathrm{D}$

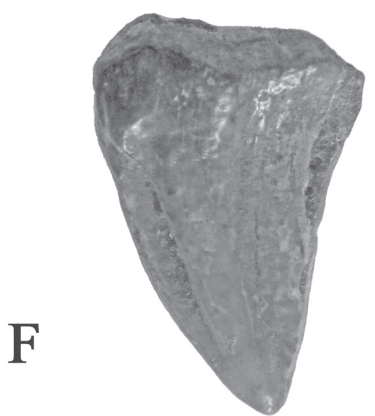

Fig. 6.-SMNS 47445, Dryopithecine right upper male canine, Neuhausen, Late Miocene (Vallesian) Bohnerzgruben, Swabian Alb, Germany. A) stereo occlusal view, B) radicular, C) buccal, D) distal, E) stereo mesial, and F) stereo lingual views (scale: $10 \mathrm{~mm}$ ). 
Table 2.-Measurements (in $\mathrm{mm}$ ) of the teeth of Dryopithecinae from Neuhausen, Swabian Alb, Germany

\begin{tabular}{lcccccc}
\hline Catalogue & Specimen & Mesio-distal length & Bucco-lingual breadth & Buccal height & Lingual height & Lingual pillar height \\
\hline SMNS 47444 & Right I1/ & 7.8 & 6.9 & 11.0 & 9.9 & $8 \mathrm{ca}$ \\
\hline SMNS 47445 & Right C1/ & 13.7 & 9.2 & 17.5 & 17.6 & - \\
\hline SMNS 43650 & Right P3/ & 6.4 & 9.5 & $7.5++$ & $4.5+$ & - \\
\hline
\end{tabular}

++ means the cusp is broken at cervix; + means the cusp apex is lightly worn.

Table 3.-Metric comparison of the Neuhausen upper central incisor with those of other dryopithecines from Spain, France and Hungary

\begin{tabular}{llccccc}
\hline Catalogue & Specimen & Mesio-distal length & Bucco-lingual breadth & Buccal height & Lingual height & Lingual pillar height \\
\hline SMNS 47444 & Right I1/ & 7.8 & 6.9 & $11.0^{*}$ & $9.9^{*}$ & $8 \mathrm{ca}$ \\
\hline IPS 1807 & Right I1/ & 7.1 & 6.1 & 11.2 & 11.2 & 7.7 \\
\hline IPS 1778 & Right I1/ & 7.0 & 6.2 & 9 & 9.4 & 5.2 \\
\hline IPS 1770 & Right I1/ & 7.7 & 7.2 & 9.1 & 9.8 & 4.4 \\
\hline IPS 1801 & Right I1/ & 7.6 & 7.0 & - & - & 4.8 \\
\hline IPS 1801 & Left I1/ & 7.6 & 7.1 & 9.5 & 11.9 & 4.0 \\
\hline IPS 21350 & Right I1/ & 9.1 & 7.7 & - & - & 7.6 \\
\hline RUD 12 & Left I1/ & 7.1 & 7.2 & - & - & - \\
\hline RUD 15 & Right I1/ & 8.3 & 7.1 & - & - & - \\
\hline RUD 15 & Left I1/ & 7.7 & 7.2 & - & - & - \\
\hline RUD 47 & Right I1/ & 8.5 & 8.3 & 6.3 & - & - \\
\hline La Grive & Right I1/ & & & - & - \\
\hline
\end{tabular}

* The Neuhausen tooth is slightly worn apically, the lingual side more than the labial side (i.e. the wear facet is inclined labio-lingually).

divergent, the angle between the roots being ca $20^{\circ}$. In mesial view, the tall central pillar gives this tooth a barrel-like profile at the base, reaching apically about $2 / 3$ the height of the crown, before the profile narrows near apex. The lingual foveae are thus high up the crown, in contrast to many Early Miocene hominoids, australopithecines and chimpanzees in which the lingual part of the crown is scooped out almost to the lingual cingulum.

In distal view the interstitial facet caused by abrasion against the I2/ is visible basally and slightly to the lingual side of the crown. The root is solid, rounded triangular in outline, narrowing apically. At the broken apex of the root the largest diameter is labio-lingual $(6.4 \times 5.2 \mathrm{~mm})$, at cervix the dimensions are subequal is $(6.8 \times 6.1 \mathrm{~mm})$.

SMNS 47445 is the crown of a lightly worn upper right canine, probably male (Fig. 4, 6). The crown is strongly labiolingually compressed with a deep and extensive mesial lingual groove, and a shallower, more open and less extensive buccal mesial groove. The latter groove extends from the cervix to half the height of the crown. The former extends from just above cervix almost to the apex, terminating about $3 \mathrm{~mm}$ from the tip of the tooth. At the base of the mesial lingual groove there is a basal mesial tubercle which separates the groove from the cervix. The crest between the two mesial grooves has a clear wear facet extending from the vicinity of the mesial tubercle apically almost to the end of the groove, stopping about $4.5 \mathrm{~mm}$ from the tip of the tooth. In lingual view, the profile of the mesial wear facet is almost flat, in fact very gently convex. The buccal side of the buccal mesial groove is bordered by a low crest. The buccal surface of the crown is generally smooth, with a hint of vertical wrinkles and it is gently convex from cervix to apex. In the centre, however, near the base of the crown there is a shallow depression with a narrow but shallow groove. A hairline crack near this groove extends to the apex of the tooth. Perikymata are clearly developed.

In mesial view the profile of the crown is convex buccally, slightly concave lingually.

A distal wear facet marks the lingual side of the distal crest of the crown, extending from the apex to cervix. Dissolution of 

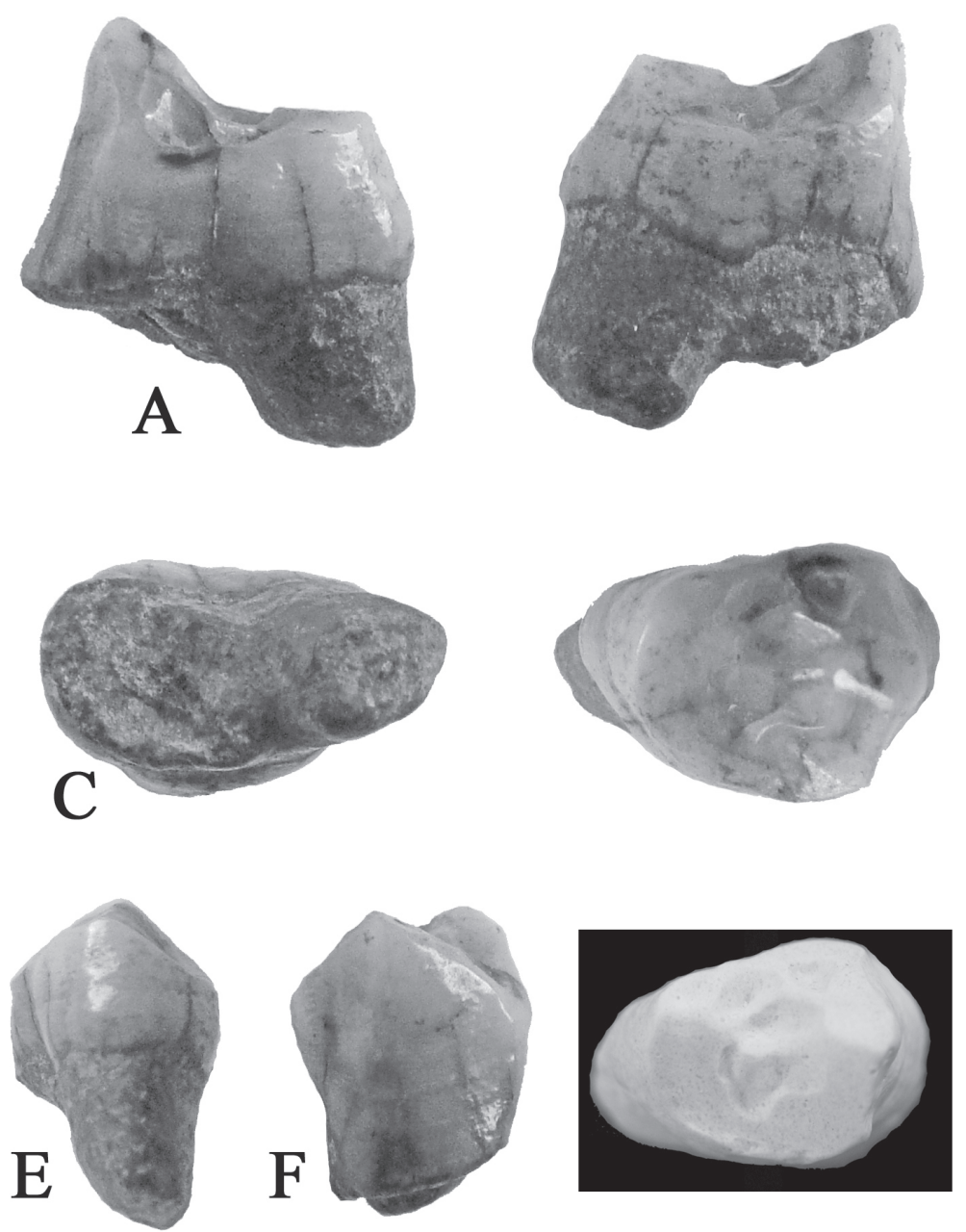
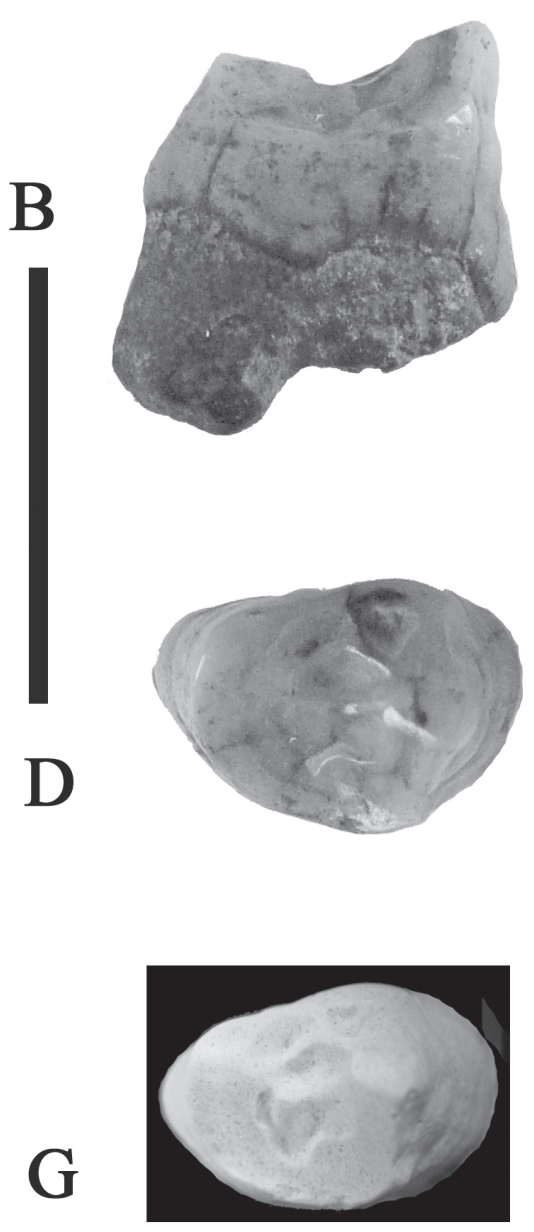

Fig. 7.-SMNS 43650, Dryopithecine left P3/, Neuhausen, Late Miocene (Vallesian) Bohnerzgruben, Swabian Alb, Germany. A) mesial, B) stereo distal view, C) radicular, D) stereo occlusal, E) buccal, and F) lingual views G) stereo occlusal view of a cast (scale: $10 \mathrm{~mm}$ ).

the exposed dentine has resulted in the development of a valley along the course of the facet along its lingual side. The lingual pillar is as tall as the crown, mesio-distally broad basally, narrowing apically, and separating the mesial groove from the lingual distal concavity. A low depression separates the lingual pillar from the basal tubercle that closes the base of the mesial groove.

In radicular view, the root section is triangular with rounded apices (13.7 mm lingual edge x $9.2 \mathrm{~mm}$ anterobuccal edge x 10 $\mathrm{mm}$ labial edge). The pulp cavity is large.

SMNS 43650 (number on old label $=284$ ) is a moderately worn upper left P3/ (Fig. 4, 7, 8). The buccal root is missing and has carried away a small portion of the crown. Otherwise the tooth is in an excellent state of preservation. In mesial view there is a depression between the roots near cervix which is reflected crownwards, fading out towards the occlusal surface. This depression is where the canine would fit snugly into a sort of niche, suggesting a lack of C-P3/ diastema in this species, as in many apes. There is a very slight interstitial wear facet on the buccal side of the depression, probably caused by the canine, but possibly also by food attrition. In mesial view it is also clear that the paracone is appreciably taller than the protocone (paracone height in mesial view $-6 \mathrm{~mm}$; protocone height in mesial view $-4 \mathrm{~mm}$ ).

In buccal view the enamel extends onto the buccal root (which has broken off) slanting slightly mesially. The parastyle is small but distinct and is separated from the main part of the paracone by a shallow dip in the enamel near the occlusal surface. This depression fades out cervically. The mesostyle is more strongly in evidence than the parastyle, forming a distinct swelling in the distal part of the buccal surface of the crown, separated from the main body of the paracone by a depression which likewise fades out cervically. In distal view the buccal profile of the paracone is slightly concave, the base of the tooth being broader than the apical part (greatest crown breadth at cervix $9.8 \mathrm{~mm}$, distance between outer edges of paracone and protocone tips as preserved $-6 \mathrm{~mm}$ ). Lingual flare of the protocone is thus moderate.

In distal view, a small interstitial wear facet caused by abrasion against the $\mathrm{P} 4 /$ is visible near the occlusal surface slightly to the lingual side of the distal surface, above the gap between the two roots. The distal cingulum is lower than the mesial one, such that the distal fovea has a greater cervico-apical depth than the mesial one. 


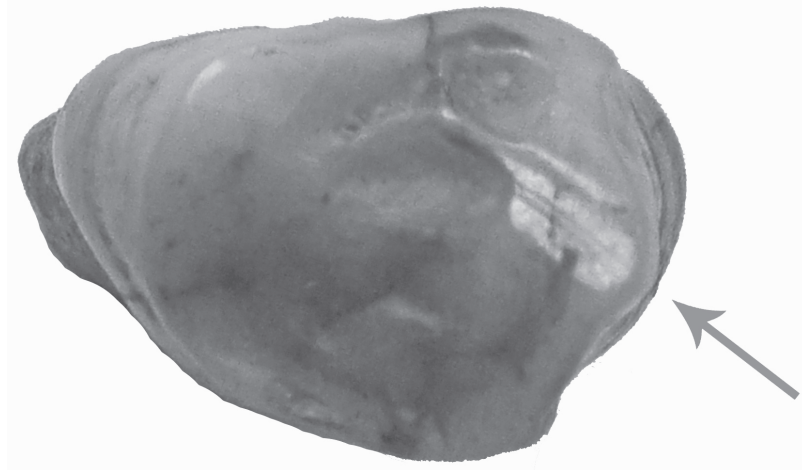

Fig. 8.-SMNS 43650, Dryopithecine left P3/, occlusal view highlighting the obliquely oriented mesial wear facet (arrow shows direction of wear striae) on the paracone parallel to the anterior ridge which unites the paracone to the protocone, and which walls off the posterior margin of the mesial fovea. Note the low crest departing mesially from the centre of the ridge, which separates the mesial fovea into two halves.

In lingual view, the protocone is narrower than the paracone, and is slightly anterior to the midline of the tooth.

In occlusal view, the mesial cingulum forms a margin to a broad but short mesial fovea, which is interrupted in its centre by a low crest that emanates from the ridge that links the paracone to the protocone, this ridge forming the distal margin of the anterior fovea. A second crest descends from the apex of the paracone across the tooth to the base of the protocone, closing off a central fovea, the floor of which is higher than the floor of the mesial fovea. Between this transverse crest and the distal cingulum, there is the distal fovea, the floor of which is lower than that of the other two foveae. The distal fovea is almost as broad as it is long.

The occlusal wear facets are clear and, for the most part, planar. Those on the mesial crests of the paracone are oriented mesio-lingually at an angle of about $30^{\circ}$ from the transverse line and they are inclined antero-lingually. The wear facet on the distal sides of the paracone and protocone are more expansive than those on the front of the tooth and they dip at a steep angle from the apices of the cusps distally before flattening out near the distal cingulum. Thus the profile of the distal wear facet is concave in lingual and buccal views.

The lingual root of the $\mathrm{P} 3 /$ slants slightly palatewards, continuing the lingual profile of the protocone. The buccal root is broken off just beneath cervix, so it is not possible to discern whether it bifurcated apically or not.

\section{Interpretation and comparisons}

\section{Upper central incisor}

The upper central incisor from Neuhausen is barrel-like rather than spatulate, which distances this tooth from hominoids with more spatulate upper incisors, including chimpanzees, gorillas, Pongo, sivapithecines, Lufengpi thecus, ouranop-

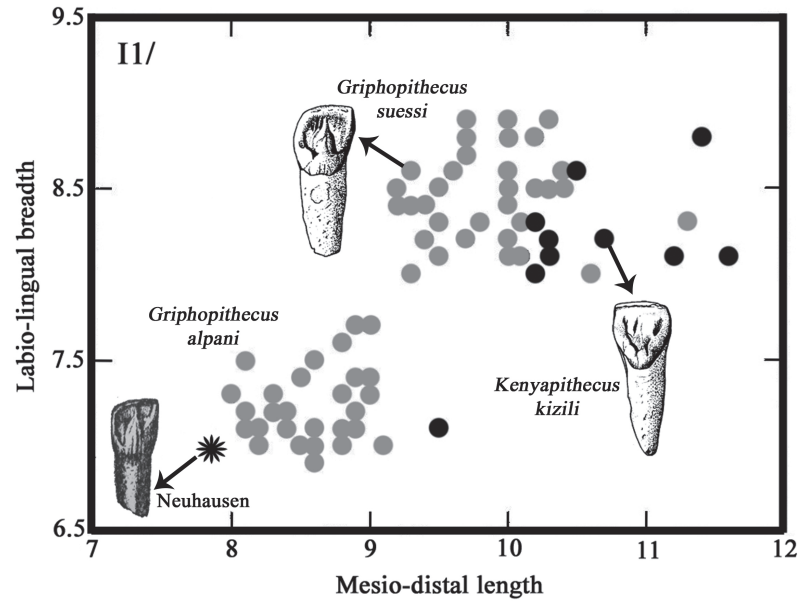

Fig. 9.-Bivariate plots of the Neuhausen upper central incisor (star) and fossils from Pa?alar, Turkey, attributed to Griphopithecus suessi (grey circles large specimens) Griphopithecus alpani (grey circles small specimens) and Kenyapithecus kizili (black circles). The Neuhausen fossil is smaller than all Pa?alar specimens, is less spatulate and possesses a relatively taller central lingual pillar. (Data for Pa?alar from Kelley et al., 2008).

ithecines, afropithecines, Otavipithecus, kenyapithecines and proconsulids. It is slightly smaller than incisors attributed to Griphopithecus from Pasalar, Turkey, and its distal margin is not quite as spatulate, but the Neuhausen and Pasalar incisors share the prominent lingual pillar and well developed lingual marginal ridges (Kelley et al., 2008 fig. 1, right image). Some of the Pasalar (Turkey, MN 6) hominoid upper central incisors show grooves either side of the central pillar on the lingual side (Alpagut et al., 1990), but the pillars are lower, and the crown more spatulate than in the Neuhausen specimen. Other upper central incisors from Pasalar attributed to Kenyapithecus kizili have a depression where the central pillar is located in other hominoids (Andrews et al., 1996; Kelley et al., 2008) and are thus markedly divergent in morphology from the Neuhausen specimen (Fig. 9).

In contrast, an upper incisor from Can Ponsic, Spain identified as Dryopithecus crusafonti by Begun (2002) shows clear grooves either side of the central lingual pillar (Ribot et al., 1996). IPS 1807 from Can Ponsic is similar morphologically and metrically to the Neuhausen specimen. Particular resemblances are the presence of deep clefts either side of the central pillar, the step-like apex of the central pillar with a narrow crest continuing until the incisive edge, the relatively tall basal pillar $(7.7 \mathrm{~mm}$ from cervix to apex, compared to a 


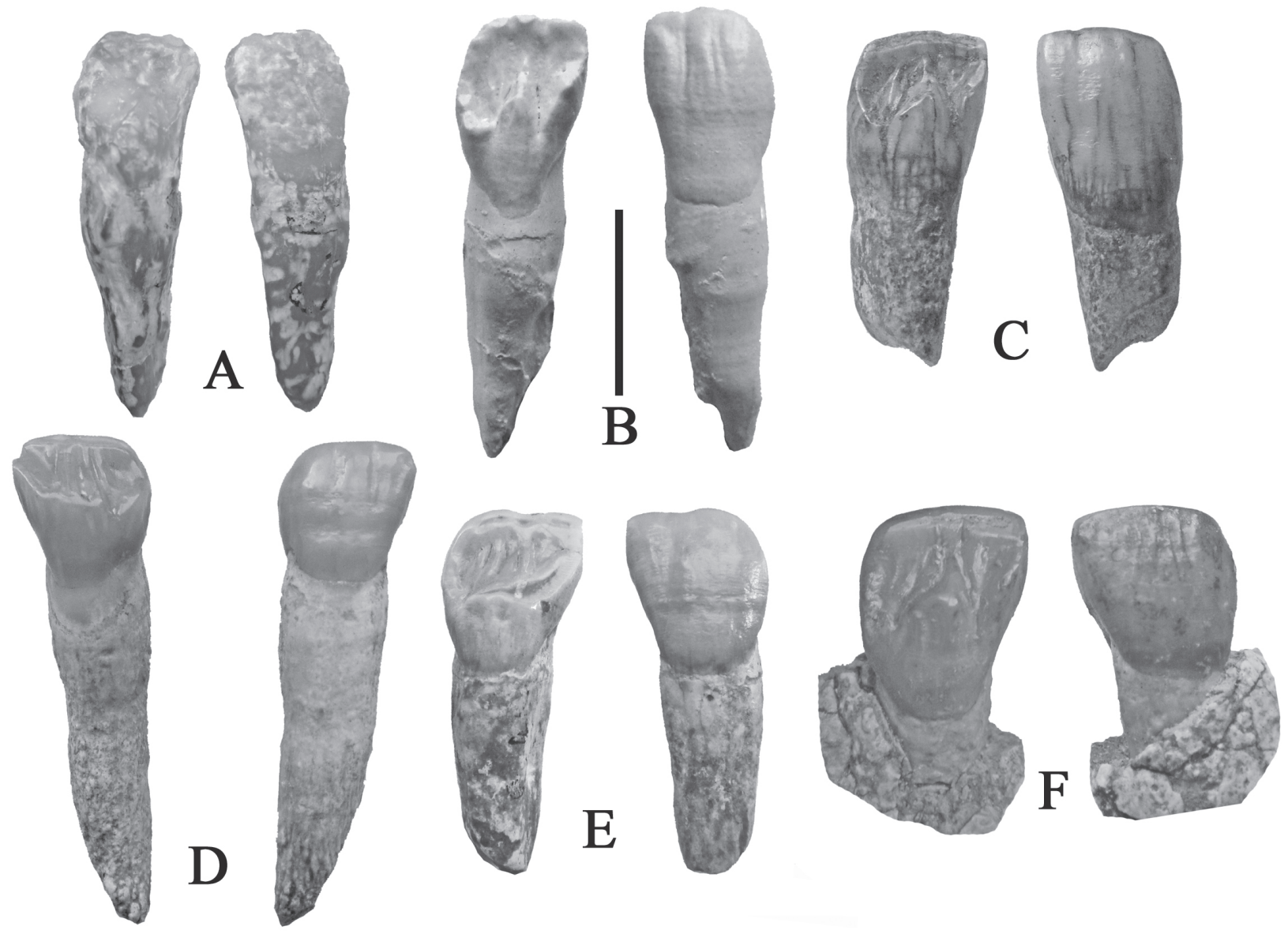

Fig. 10.-Upper central incisors of Spanish and German dryopithecines, lingual (left image) and labial views. A) IPS 1778 and B) IPS 1907, Dryopithecus crusafonti from Can Ponsic, Spain, right I1/s (note the two grooves on the labial surface of IPS 1907); C) SMNS 47445, right I1/; D) IPS 18000, Hispanopithecus laietanus, left I1/; E) IPS 1770, Hispanopithecus laietanus, right I1/; F) IPS 21350, Pierolapithecus catalaunicus, right I1/ (scale bar : $10 \mathrm{~mm}$ ).

total lingual crown height of $11.2 \mathrm{~mm}$ ) the presence of labial grooves, one near the mesial side, the other near the distal side corresponding in position to the clefts on the lingual side. Other Spanish hominoid upper central incisors resemble the Neuhausen specimen, both in dimensions and morphology, including IPS 1809 and IPS 1807 from Can Ponsic. In particular, the distal edge of the crown is not spatulate, the lingual pillar is strongly developed and has a crest that extends apically towards the cutting edge of the tooth, and there are strong grooves (clefts) either side of the lingual pillar (Ribot et al., 1996). In isolation and in combination, these characters are unusual among hominoid upper central incisors, and indicate that the Neuhausen and Can Ponsic incisors have a high probability of belonging to the same species. Begun (2009) has recently accepted the validity of
Hispanopithecus, and now includes the species $H$. crusafonti in this genus, a combination first proposed by Moyà-Solà et al. (2009a).

The Neuhausen incisor resembles that of Pierolapithecus catalaunicus by the presence of clefts either side of the central lingual pillar, but the crown of the Spanish incisor is more spatulate, and there are no grooves on the labial surface, which is gently convex throughout and covered in finely wrinkled enamel, unlike the smoother enamel of the Neuhausen specimen. The incisor from La Grive, France, is similar to that of Pierolapithecus catalaunicus, and because of this Begun (2009) classified the species catalaunicus in Dryopithecus.In contrast, I take this tooth to provide evidence that Pierolapithecus occurred in France, the maxilla attributed to Dryopithecus fontani by Moyà-Solà et al., (2009a) shows numerous differences in dental and cranial 
morphology from Pierolapithecus. Moyà-Solà et al. (2009a) considered that the specimens from La Grive belong to Dryopithecus fontani because they display "higher-crowned and relatively much broader molars as well as hypsodont and narrow I2/" than occur in P. catalaunicus. My own assessment of the incisor is that it is close in shape and dimensions to that of P. catalaunicus (Fig. 10F). The canines indicate that the two species fontani and catalaunicus are not closely related.

The Neuhausen upper incisor differs markedly from those of Hispanopithecus laietanus in a number of morphological features, as well as by its superior dimensions. H. laietanus incisors are lower crowned, the lingual pillar is absent, its place occupied by two low subvertical crests of enamel, the mesial lingual cleft is absent, and the distal lingual cleft is minute (Fig. 10).

Unfortunately the upper incisors of Anoiapithecus brevirostris and Dryopithecus fontani are unknown (the specimen from La Grive previously attributed to $D$. fontani belongs, in my assessment, to Pierolapithecus catalaunicus).

Neuhausen incisor differs markedly from an upper incisor from Götzendorf, Austria, attributed to Dryopithecus brancoi by Zapfe (1989) which is more spatulate and has no lingual pillar. The Götzendorf specimen has a low crown and gracile root, suggesting that it might represent a deciduous incisor rather than a permanent one, or that it might not represent a dryopithecine. Andrews et al. (1996) classified the Götzendorf fossil as a pliopithecoid Anapithecus hernyaki. Upper central incisors from Rudabánya attributed to Dryopithecus brancoi by Begun (2002) are reported to be sexually dimorphic, with males possessing more spatulate crowns and females less spatulate ones. If so then the Hungarian species is unusual because most hominoids have monomorphic and unimodal upper incisors. The Neuhausen specimen does not resemble that of RUD 12, which has a weak to absent central lingual pillar, a spatulate distal crown, and no crest apically of the pillar. A difference from other specimens from Rudabánya is that the Hungarian material apparently lacks the grooves or clefts either side of the central pillars that are present in the Neuhausen tooth.

The presence, in the Neuhausen incisor, of a large and tall central lingual pillar separated from the mesial and distal marginal ridges by vertical grooves or clefts, recalls the condition in Late Miocene Oreopithecus, but the crown is taller than

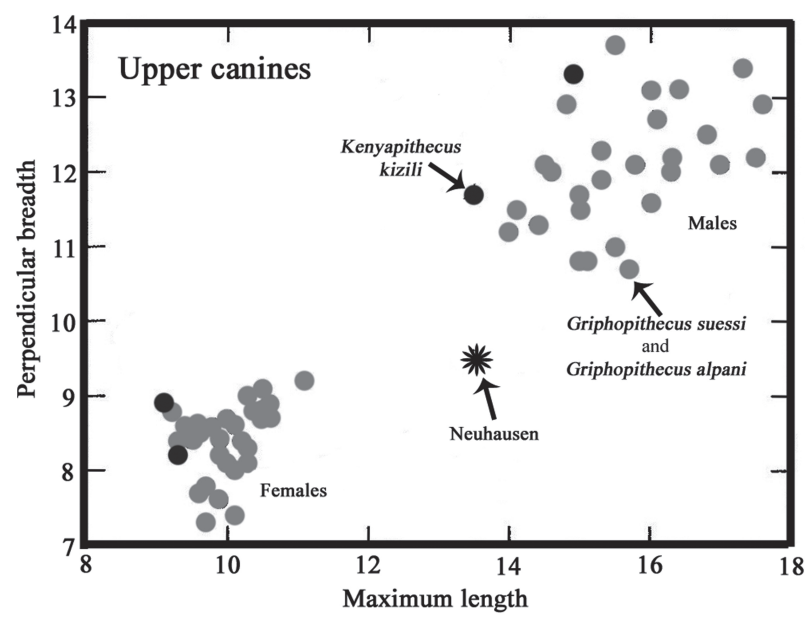

Fig. 11.-Bivariate plots of the Neuhausen upper canine and material from $\mathrm{Pa}$ ?alar, Turkey attributed here to Griphopithecus suessi, Griphopithecus alpani and Kenyapithecus kizili. The Neuhausen specimen is a male based on its morphology, and is smaller than all male $\mathrm{Pa}$ ?alar canines. (Data for $\mathrm{Pa}$ ?alar from Kelley et al., 2008).

that of the Tuscan ape. The presence of vertical enamel wrinkles on the lingual surface of the central pillar is a superficial similarity to Oreopithecus, but the overall morphology and dimensions of the tooth excludes a close relationship between these taxa.

In conclusion, the dimensions and morphology of the Neuhausen upper incisor are compatible with identification as Dryopithecus crusafonti. The tooth has some resemblances to the homologous tooth in Pierolapithecus catalaunicus, but the more spatulate crown, the wrinkled labial enamel and the lack of grooves labially indicate that it does not belong to this taxon. Its generic status remains to be resolved. On the basis of cheek tooth dimensions, it is expected that Anoiapithecus upper central incisors would be about the same as the Neuhausen tooth, in which case the German tooth could belong to one of two taxa, Dryopithecus crusafonti (but see discussion below) or Anoiapithecus brevirostris.

\section{Upper canine}

The Neuhausen upper canine evidently represents a young male individual, judging from the dimensions and morphology of the crown (Pickford \& Chiarelli, 1986). It is dagger-like, as in Oreopithecus, but the buccal enamel does not have the vertical enamel ridges (fluting) on the labial surface that 


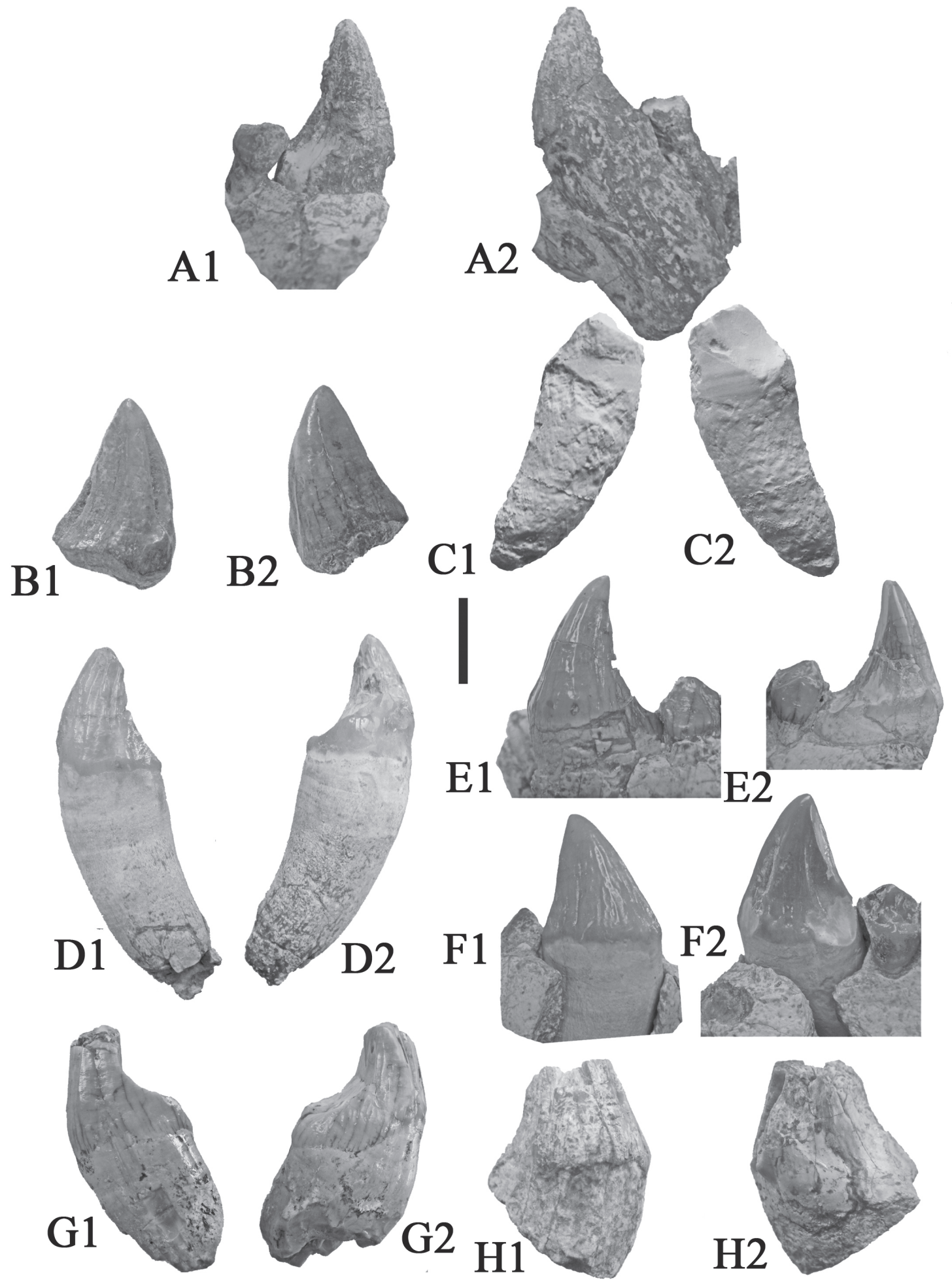

Fig. 12.-Upper canines of Spanish and German hominoids. A) IPS 43000, Anoiapithecus brevirostris, right canine, lingual and buccal views; B) SMNS 47445, right canine, lingual and buccal views; C) IPS 1798, Dryopithecus crusafonti, left canine, buccal and lingual views; D) IPS 35026, Dryopithecus fontani, right canine, buccal and lingual views; E) IPS 18000, Hispanopithecus laietanus, right canine, buccal and lingual views; F) IPS 21350, Pierolapithecus catalaunicus left canine, buccal and lingual views; G) IPS 1801, Hispanopithecus laietanus, right canine, buccal and lingual views; H) IPS 14741, Hispanopithecus laietanus, left canine, buccal and lingual views (scale: $10 \mathrm{~mm}$ ). 
Table 4.-Metric comparison of the Neuhausen upper male canine (CM/) with specimens from Spain and Hungary

\begin{tabular}{llccccc}
\hline Catalogue & Specimen & Mesio-distal length & Bucco-lingual breadth & Buccal height & Lingual height & Taxon \\
\hline SMNS 47445 & Right CM/ & 13.7 & 9.2 & 17.5 & 17.6 & A. brevirostris \\
\hline IPS 43000 & Right CM/ & 14.1 & 9.4 & 18.7 & 17.7 & A. brevirostris \\
\hline IPS 1801 & Right CM/ & 14.6 & 10.9 & - & - & H. laietanus \\
\hline IPS 18000 & Right CM/ & 12.4 & 10.3 & $16++$ & $17.7++$ & H. laietanus \\
\hline IPS 21350 & Right CM/ & 15.3 & 11.1 & 18.7 & 18.1 & P. catalaunicus \\
\hline IPS 21350 & Left CM/ & 15.3 & 10.9 & 17.7 & 18.3 & P. catalaunicus \\
\hline IPS 1798 & Left CM/ & 12.0 & 9.4 & - & - & D. crusafonti \\
\hline IPS 35026 & Left CM/ & 16.8 & 12.2 & - & 20.0 & D.fontani \\
\hline IPS 35026 & Right CM/ & 17.6 & 13.0 & 21.0 & 20.8 & D.fontani \\
\hline RUD 44 & Left CM/ & 12.5 & 8.5 & - & - & B. altipalatus \\
\hline
\end{tabular}

A. Anoiapithecus; B. Bodvapithecus; D. Dryopithecus; H. Hispanopithecus; P. Pierolapithecus. ++ - damaged specimen.

occurs in the Tuscan species. The presence of a groove on the buccal side of the crown recalls the situation in Dendropithecus macinnesi from East Africa (Andrews, 1978; Andrews \& Simons, 1977), as does the slender dagger-like crown shape and the presence of lingual and buccal mesial grooves separated by a prominent crest along which the main mesial wear facet is formed (Pickford et al., 2010). A further resemblance between the Neuhausen canine and that of Dendropithecus is the shape and extent of the lingual pillar, broad mesio-distally at the base, narrowing apically, with a large scoopshaped depression between it and the distal margin of the crown. Buccal grooves occur in Anoiapithecus, Pierolapithecus, Hispanopithecus and Dryopithecus, but they are generally absent in East African early and middle Miocene taxa (Proconsul, Ugandapithecus, Afropithecus).

The Neuhausen canine is smaller than any of the male canines from Pasalar (Turkey) (Kelley et al., 2008) (Fig. 11) but is considerably larger than any of the female specimens. The morphological description of the male upper canines from Pasalar (Kelley et al. 2008) accords with that of the Neuhausen specimen.

Upper canines of Hispanopithecus laietanus from Spain have been described as quite dagger-like (Moyà-Solà \& Köhler, 1995) but they are broader bucco-lingually than the Neuhausen specimen, the buccal enamel is strongly wrinkled, and the mesial groove is broader. The male upper canine from Can Llobateres is larger $(15 \times 11 \mathrm{~mm})$ and was considered by Ribot et al. (1996) to be not so dagger-like. The same applies to some specimens from Rudabánya, such as RUD 44 (Begun, 2002; Kordos, 1991; Kordos \& Begun, 2001). As with the incisors, there is a specimen from Can Ponsic, which is close in dimensions to the Neuhausen canine, but the crown of the Spanish fossil is damaged and worn (Fig. 12, Table 4), so that detailed comparisons are not possible. The canines in the snout of Dryopithecus fontani from Els Hostalets de Pierola (MoyàSolà et al., 2009a) are dagger-like with vertically wrinkled buccal enamel, but they are appreciably bigger than the Neuhausen specimen, and the mesial and buccal grooves are broader, making it unlikely that the German specimen belongs to Dryopithecus fontani. Of all the upper canines from Spain, that of Anoiapithecus brevirostris is closest in dimensions and morphology to the Neuhausen specimen.

In conclusion, the Neuhausen canine is compatible in dimensions and morphology with the holotype of Anoiapithecus brevirostris (Fig. 13). It is metrically similar to the Can Ponsic canine, but the crown morphology of the latter specimen is so poorly preserved that no meaningful comparison can be made. 

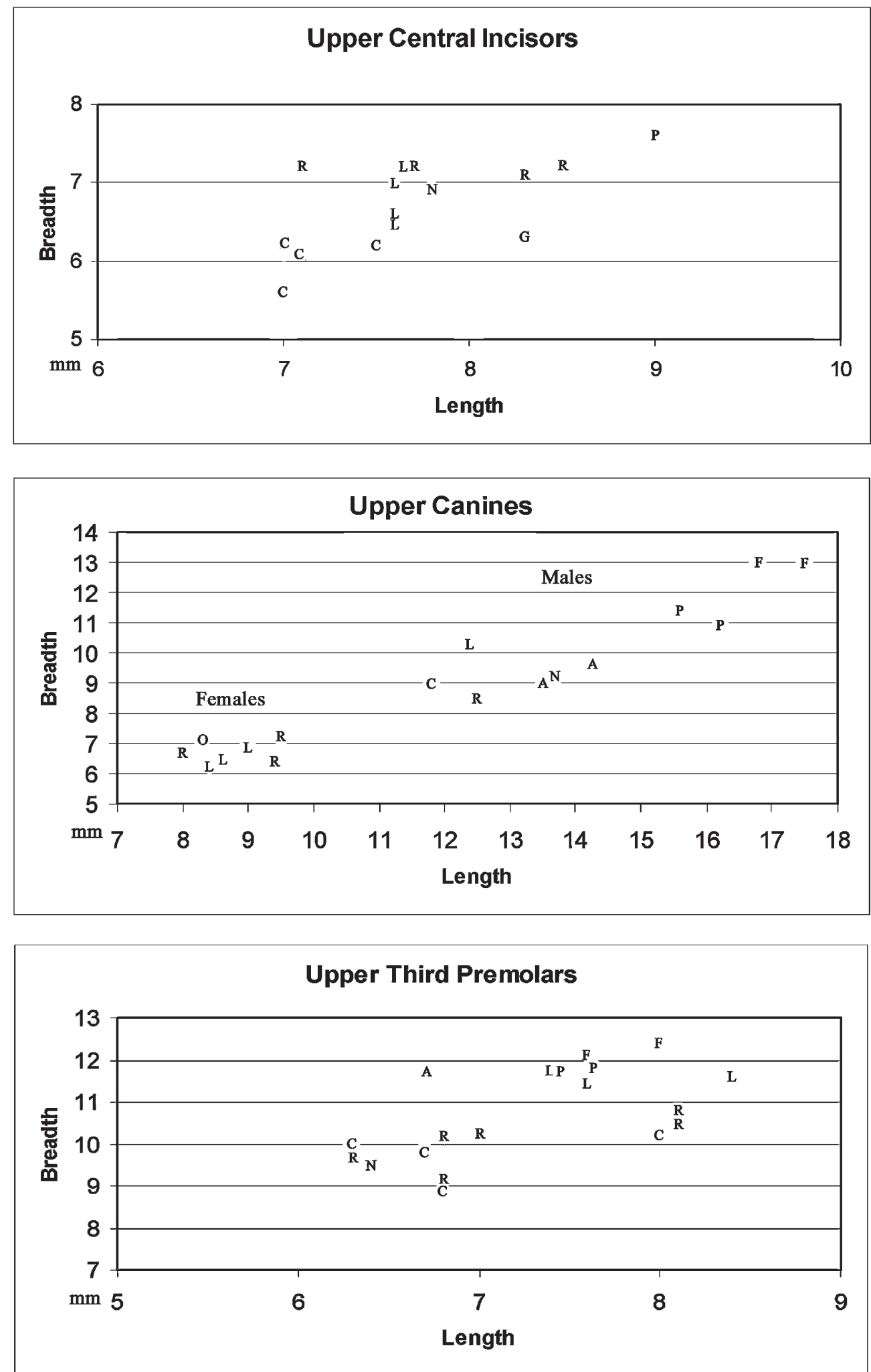

Fig. 13.-Bivariate plots (length $\mathrm{x}$ breadth) of dryopithecine teeth from Europe. A - Anoiapithecus brevirostris, C - Can Ponsic, $\mathrm{F}-$ Dryopithecus fontani, G - La Grive St-Alban, L - Can Llobateres (Hispanopithecus laietanus), N - Neuhausen, O - Polinyà II, P Pierolapithecus catalaunicus, R - Rudabánya. 
Table 5.-Metric comparison $(\mathrm{mm})$ of the Neuhausen dryopithecine P3/ and material from Spain and Hungary

\begin{tabular}{|c|c|c|c|c|c|c|}
\hline Catalogue & Specimen & Mesio-distal length & Bucco-lingual breadth & Buccal height & Lingual height & Taxon \\
\hline SMNS 43650 & Right P3/ & 6.4 & 9.5 & $7.5++$ & $4.5+$ & A.. b. or D.c. \\
\hline IPS 35026 & Right P3/ & 7.7 & 12.0 & $9.1+$ & $5.3+$ & D. fontani \\
\hline IPS 35026 & Left P3/ & 7.5 & 12.3 & $8.3+$ & $6.3+$ & D. fontani \\
\hline IPS 18000 & Left P3/ & 6.3 & 10.7 & 7.3 & 5.8 & H. laietanus \\
\hline IPS 18000 & Right P3/ & 7.1 & 11.8 & 9.3 & 5.8 & H. laietanus \\
\hline IPS 1792 & Right P3/ & 8.0 & 11.8 & 9.6 & 6.2 & H. laietanus \\
\hline IPS 21350 & Left P3/ & 7.3 & 11.5 & 8.6 & 6.2 & P. catalaunicus \\
\hline IPS 21350 & Right P3/ & 7.8 & 11.9 & 8.9 & 6.4 & P. catalaunicus \\
\hline IPS 1798 & Left P3/ & 7.5 & 10.8 & $9+$ & 5.2 & D. crusafonti \\
\hline IPS 43000 & Left P3/ & 6.7 & 11.6 & 9.0 & 6.0 & A. brevirostris \\
\hline RUD 05 & Right P3/ & 6.8 & 9.2 & - & - & R. hungaricus \\
\hline RUD 12 & Left P3/ & 6.3 & 9.7 & - & - & R. hungaricus \\
\hline RUD 15 & Right P3/ & 7.0 & 10.3 & - & - & R. hungaricus \\
\hline RUD 15 & Left P3/ & 6.8 & 10.2 & - & - & R. hungaricus \\
\hline RUD 44 & Right P3/ & 8.1 & 10.5 & - & - & B. altipalatus \\
\hline RUD 44 & Left P3/ & 8.1 & 10.8 & - & - & B. altipalatus \\
\hline
\end{tabular}

A. b. - Anoiapithecus brevirostris; B - Bodvapithecus; D - Dryopithecus; D. c. - Dryopithecus crusafonti (possibly the same species as Udabnopithecus garedziensis; $\mathrm{H}$ - Hispanopithecus; R - Rudapithecus.

+ : minor wear at cusp apex, ++ : base of cusp broken.

\section{Upper third premolar}

The upper third premolar from Neuhausen, in which the paracone has a concave buccal profile from cervix to apex, recalls the situation in the Georgian dryopithecine, Udabnopithecus garedziensis (Burtschak-Abramovitsch \& Gabachvili, 1946, 1950 ) in which the $\mathrm{P} 4 /$ has a similar profile (the Georgian specimen is missing the P3/) (Fig. 14). Another similarity is the production of planar wear facets (personal observation of original fossils), almost like crystal faces, rather than smooth, rounded wear surfaces such as those that typify Kenyapithecus, Griphopithecus and Ouranopithecus for example, but this could be related to the relatively juvenile state of wear in the Neuhausen tooth. The buccal profile of the P3/ in the Pasalar (Turkey) hominoids is straighter or even slightly convex and the crowns are more mesio-distally compressed than in the Neuhausen specimen.
The Neuhausen P3/ is similar in its occlusal outline to specimens from Rudabánya, such as RUD 12, identified as Rudapithecus hungaricus Kretzoi (1969: the date 1967 given by McKenna \& Bell, 1997, appears to be an error) by Kordos (1991), more recently attributed to Dryopithecus brancoi (Begun, 2002) although this attribution is probably incorrect (see below). It is similar in dimensions and morphology to specimens from Can Ponsic in Spain (Dryopithecus crusafonti), but is smaller and bucco-lingually narrower than material from Can Llobateres attributed to Hispanopithecus laietanus, which differs by having a weak transverse crest running from the paracone towards the centre of the tooth. Like the Can Ponsic holotype of Dryopithecus crusafonti, and the type specimen of Udabnopithecus garedziensis, the wear facets are sharp edged and planar, like crystal faces.

The Neuhausen P3/ is slightly smaller than the smallest of the upper third premolars from Pasalar 

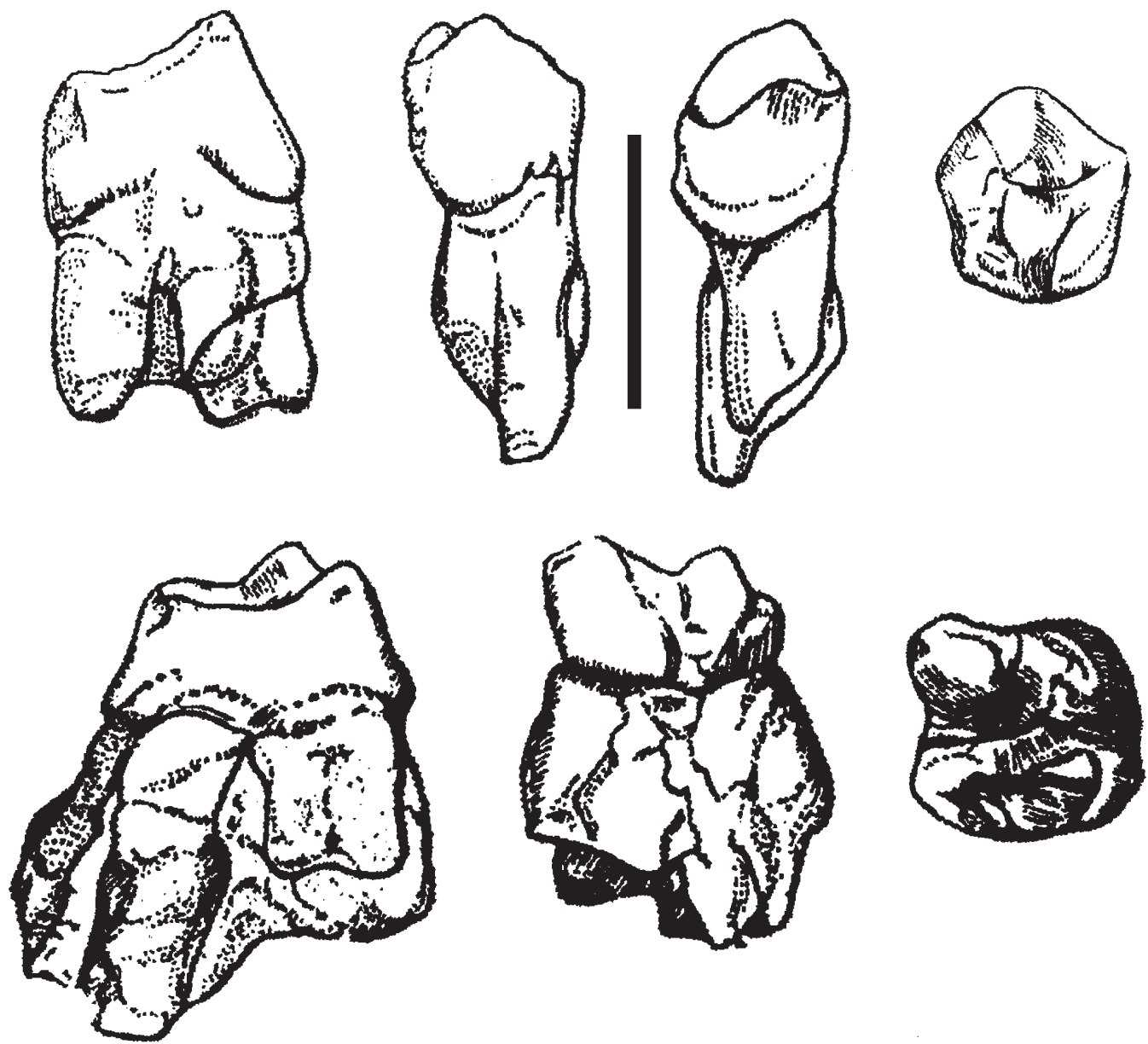

Fig. 14.- - Holotype of Udabnopithecus garedziensis from Udabno, Georgia, right P4/ (top row) and M1/ (bottom row) showing the slightly concave buccal profile of the P4/ (modified from Burtschak-Abramovitsch \& Gabachvili, 1950). (Top row from left to right: mesial, buccal, lingual and occlusal views: Bottom row from left to right, mesial, buccal and occlusal views) (scale bar : $10 \mathrm{~mm}$ ).

(Turkey) attributed to Griphopithecus and Kenyapithecus (Kelley et al., 2008) (Fig. 15). However, the morphology is not similar especially the buccal surface of the paracone which, in the Turkish specimens, is convex from apex to cervix.

The P3/ from Neuhausen differs from those of Dryopithecus fontani from Spain by its smaller dimensions, but its basic morphology is similar, although in $D$. fontani the anterior fovea is not subdivided into two by a crest leading anteriorly from the lingually directed paracone crista. The closest match for the German tooth is with the P3/ in the holotype of $A$. brevirostris, a male specimen, save for the weaker distal transverse crest leading from the paracone, the more flaring lingual and buccal cusp walls and the stronger parastyle.

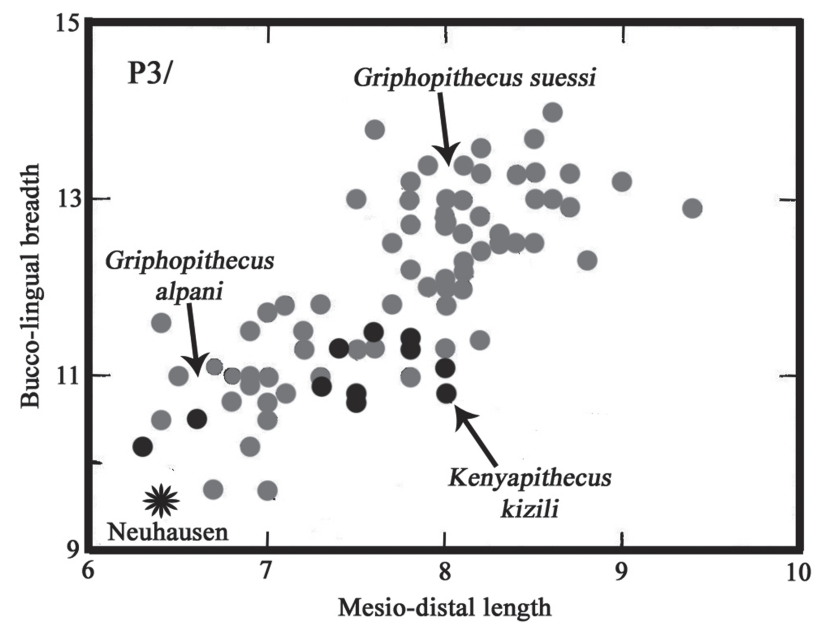

Fig. 15.-Bivariate plots of the Neuhausen P3/ and specimens from Pa?alar, Turkey. The Neuhausen specimen is smaller than all P3/s from Pa?alar. (Data for Pa?alar from Kelley et al., 2008). 


\section{Discussion}

\section{Affinities of the Neuhausen dryopithecine teeth}

All three teeth from Neuhausen belong to young adult individuals, wear on the upper incisor and caninebeing light, that on the $\mathrm{P} 3 /$ being light to moderate. It is possible that these teeth represent a single individual in which the premolar is slightly more worn than the incisor and canine, but there is no way of demonstrating this. In contrast, the state of preservation of the canine and incisor are somewhat different (the canine is brownish, the incisor bluish-grey with manganese streaks in cracks), suggesting slightly different taphonomic histories, which would indicate that the teeth likely represent three separate individuals.

The three Neuhausen teeth show clear morphological and metric affinities with some specimens from Spain. The I1/ is close to fossils from Can Ponsic currently identified as Dryopithecus crusafonti, although the generic status of this species remains to be established (its appurtenance to Udabnopithecus needs to be explored). Its incisors, canine and P3/ suggest that it is likely to lie closer to Anoiapithecus and to Pierolapithecus than to Dryopithecus. Likewise it is not closely related to Hispanopithecus.

The Neuhausen canine is similar to those of males of Anoiapithecus brevirostris, but is not very different from those of Pierolapithecus catalaunicus (the main difference is the greater dimensions and the stronger buccal enamel wrinkling in P. catalaunicus). It is highly divergent from the canines of Hispanopithecus laietanus and Dryopithecus fontani, which are broader bucco-lingually, have broader mesial grooves, a broader buccal groove, and heavily wrinkled buccal enamel.

The Neuhausen P3/ is morphologically and metrically closest to that of Anoiapithecus brevirostris, but it also close to the type specimen of Dryopithecus crusafonti from Can Ponsic.

Although working with isolated teeth has its disadvantages, comparison with a good sample of Spanish fossils belonging to four different species, shows that the Neuhausen teeth do not belong to Dryopithecus or Hispanopithecus both of which possess upper central incisors, upper canines and $\mathrm{P} 3 / \mathrm{s}$ which are markedly different from their homologues from Neuhausen. Deciding whether the German teeth belong to Anoiapithecus or to the Can Ponsic genus is more delicate. The upper central incisor of Anoiapithecus brevirostris is unknown, and the only upper canine from Can Ponsic is severely damaged, making comparisons difficult. However, its length and breadth dimensions are close to those of the Neuhausen canine. Whatever the case, the new material from Germany indicates that the species was widespread in Western Europe (Spain, Germany and likely Georgia).

What this study also reveals is that Pierolapithecus and Anoiapithecus are more closely related to each other in a number of dental features, than either is to Hispanopithecus or Dryopithecus, and that the Can Ponsic species D. crusafonti is more likely to belong to the Anoiapithecus-Pierolapithecus group than to Hispanopithecus or Dryopithecus.

It is therefore concluded that the Neuhausen dryopithecine teeth are most similar to Anoiapithecus brevirostris Moyà-Solà, Alba, D., Almécija, S., Casanovas-Vilar, I., Köhler, M., Esteban-Trivigno, S., Robles, J., Galindo, J. \& Fortuny, J., 2009b.

They are less likely to represent Neopithecus brancoi, which most closely resembles Spanish material from Can Vila previously identified as "Sivapithecus" occidentalis Villalta \& Crusafont (1944). The latter species was considered to be a nomen dubium by Moyà-Solà et al. (2004) but given the close morphological and metrical similarities between the holotype of Neopithecus brancoi and the holotype of Sivapithecus occidentalis, I consider that they represent one and the same species, Neopithecus brancoi. Further study of the fossils is required, especially microct scans which may reveal useful information concerning enamel thickness, root morphology and the topography of the dentineenamel junction.

\section{History of study of German hominoids}

Prior to the recognition of the Neuhausen teeth, all the hominoid fossils from the Swabian Alb deposits were molarssome of them passed through the hands of Jäger (1835) who identified one as Anoplotherium sp., (a lower molar from Salmendingen, identified as a pliopithecoid, Anapithecus hernyaki, by Begun (1989) but more properly a deciduous lower molar of Dryopithecus). Subsequently, Jäger (1850) identified lower molars from Salmendingen and Ebingen as 'Homo', which were later attributed to Paidopithex suevicus Koken (1905) but more recently included in Dryopithecus brancoi by Begun (2002; Begun \& Kordos, 1993, 
Table 6.-List of hominoid molars from the Swabian Alb and the Rhine Graben, Germany

\begin{tabular}{|c|c|c|c|c|c|}
\hline Catalogue & Illustrations & Specimen & Mesio-distal length & Bucco-lingual breadth & Locality/Identification \\
\hline GPIT MA $2127 *$ & B $1-2$ & M1/ right (M2/,) & 10.2 & 11.2 & Melchingen $N . b$. \\
\hline GPIT MA 2126§ & B 1-1 & M2/ left & 10.8 & 11.2 & Melchingen $D . f$. \\
\hline SMNS ENG 4-1 & - & M3/ right & - & 11.7 & Engelswies indet. \\
\hline GPIT MA $2122 \S$ & В 2-6 & $\mathrm{m} / 2$ left $($ or $\mathrm{m} / 3)$ & 11.0 & 9.5 & Trochtelfingen H.l. \\
\hline GPIT MA $2125 \S$ & B 2-4 & $\mathrm{m} / 2$ right (or $\mathrm{m} / 1$ ) & 9.9 & 9.1 & Melchingen N.b. \\
\hline GPIT MA $2124 \S$ & B 2-11 & $\mathrm{m} / 3$ left & 10.8 & 8.1 & Salmendingen $N . b$. \\
\hline GPIT MA $2123 \S$ & В $1-6,2-1$ & $\mathrm{~m} / 3$ right & 13.0 & 11.0 & Melchingen $D . f$. \\
\hline GPIT MA 2128 & S $1-5$ & $\mathrm{~m} / 1$ right & 9.6 & $7.6 \mathrm{e}$ & Melchingen H.l. \\
\hline SMNS $14513 \S$ & B 2-7 & m/1 left (or m/2) & 10.6 & 9.1 & Ebingen $D . f$. \\
\hline SMNS 43459§ & B 2-2 & $\mathrm{m} / 1$ right (or $\mathrm{m} / 2$ ) & 11.8 & 10.1 & Salmendingen $D . f$. \\
\hline SMNS $43460 \S$ & J 5-72-75 & $\mathrm{dm} / 4 \mathrm{left}$ & 9.1 & 7.0 & Salmendingen $D . f$. \\
\hline BSPG 1952 I 102 & V & $\mathrm{m} / 2$ right cast & 10.8 & 9.4 & Wissberg $D . f$. \\
\hline Haupt 1935 & - & Lower molar & 8.4 & 7.3 & Eppelsheim indet. \\
\hline
\end{tabular}

B - Branco, 1898; J - Jäger, 1835; S - Schlosser, 1902, V - Von Koenigswald, 1956a.

$\S$ These teeth were attributed to Dryopithecus fontani by Simons \& Pilbeam, 1965.

* This tooth was attributed to Ramapithecus punjabicus by Simons \& Pilbeam, 1965 as an M1/. Identifications proposed here after comparisons with the Spanish, Hungarian and Slovakian and Austrian hominoids: D.f. - Dryopithecus fontani; H.I. - Hispanopithecus laietanus; N.b. - Neopithecus brancoi; indet. - Indeterminate (e: estimated measurement)

1997). Until the recognition of the Neuhausen dryopithecine teeth, the sample of hominoid teeth from the Swabian Alb comprised 11 isolated molars (Table 6) (Branco, 1898) and that from the Rhine Graben, two teeth (Von Koenigswald, 1956). The molar attributed to Rhenopithecus eppelsheimensis (Haupt, 1935) is currently indeterminate (Von Koenigswald, 1956), but may prove to be a deciduous tooth of a hominoid.

The debate about the hominoids from the Swabian Albis long and complex. There are three basic proposals in recent literature about the type specimen of Neopithecus brancoi (Tübingen collection GPIT MA 2124) from Salmendingen1) that it belongs to Dryopithecus (Abel, 1931; Begun, 2002; Remane 1921), 2) that it represents Pliopithecus (Hürzeler, 1954), 3) that it is incertae sedis (Andrews et al., 1996). A fourth possibility, seldom if ever evoked since the genus was erected in 1902, is that Neopithecus is a valid genus distinct from Dryopithecus and Pliopithecus. This possibility warrants detailed examination, especially in view of recent discoveries in Spain of a high diversity of
Miocene hominoids. In particular, the holotype of the type species (Neopithecus brancoi) is similar in dimensions and most morphological details to the holotype of Sivapithecus occidentalis Villalta \& Crusafont (1944) from Can Vila, Spain and Rahonapithecus sabadellensis Crusafont \& Hürzeler (1969). The holotype of "Sivapithecus" occidentalis is a partial tooth row (left $\mathrm{m} / 2-\mathrm{m} / 3$ ) with unworn crowns marked by thick wrinkles on the occlusal surface, whereas that of Neopithecus brancoi is a moderately worn $\mathrm{m} / 3$, but despite the wear, the crown retains evidence of wrinkles which are disposed like those of the Can Vila specimen. The similarity with Rahonapithecus sabadellensis is even more striking, as it shares with the Salmendingen tooth a mesio-distally broad mesial fovea, and like them, it is a thick enamelled form with steep lingual and buccal walls, and no dentine is exposed despite the moderate stage of wear.

Six molars (Fig. 21) housed at Tübingen University were labelled Dryopithecus suevicus, but for a while were called Dryopithecus germanicus Abel, (1919) and were sometimes referred to Dryopithe- 
HOMINIDAE

HYLOBATINAE

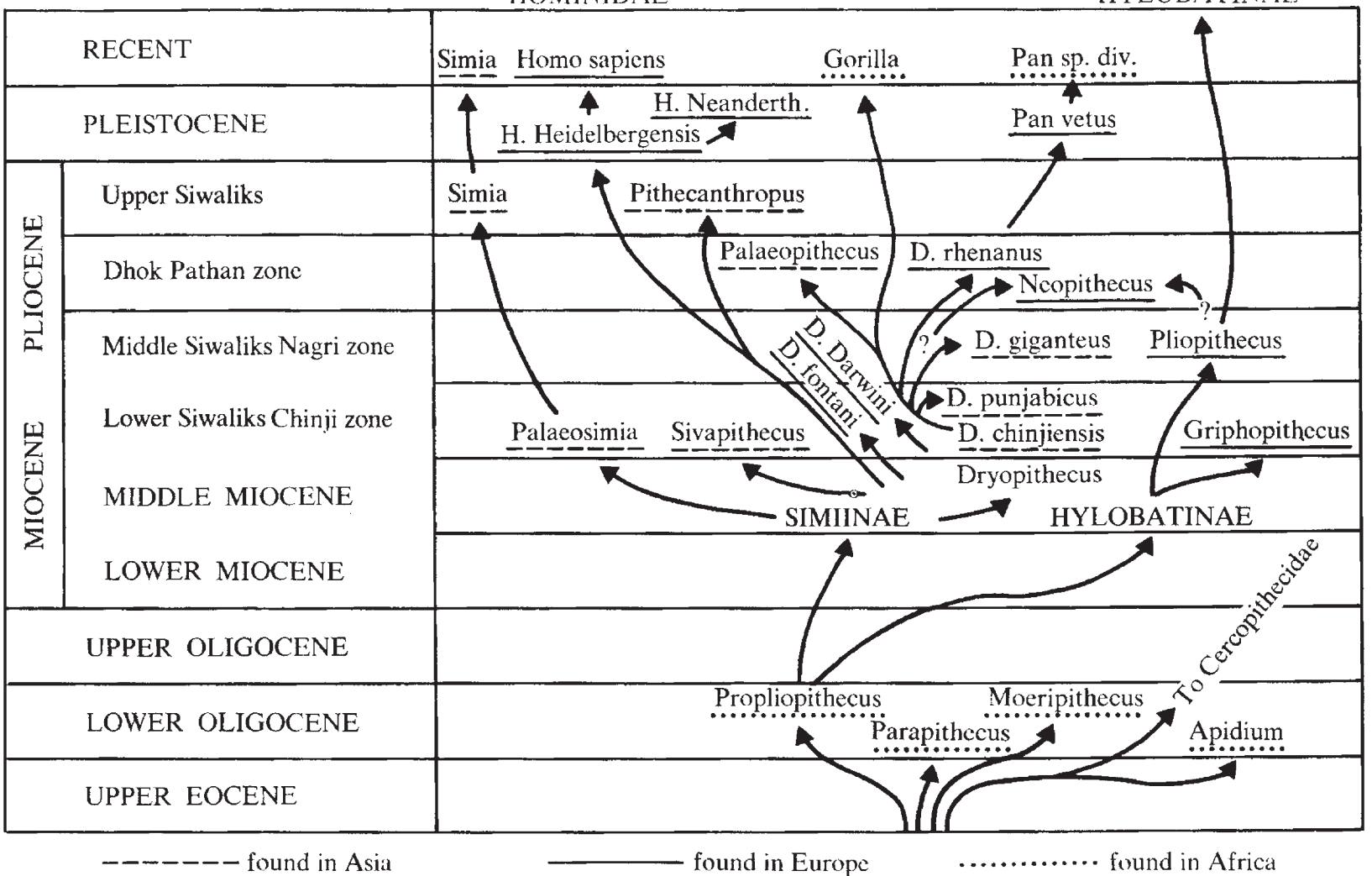

Fig. 16.-Phylogeny of Hominidae and Hylobatinae proposed by Gregory, 1916. Note that Gregory was ambivalent about Neopithecus, deriving it with question marks from either Pliopithecus or Dryopithecus. This ambivalence has persisted until recently. Note also the position of $D$. rhenanus in line between older Dryopithecus species and Pan vetus which represents the fraudulent Piltdown mandible. In fact, both $D$. rhenanus and Neopithecus should be moved down into the preceding period (equivalent to the Middle Siwaliks) (Mein, 1986; Steininger, 1986).

cus rhenanus (Gregory, 1916) (Fig. 16). There are likely three taxa represented, a large species with thin molar enamel, well expressed occlusal wrinkles and high relief dentine horns as in Dryopithecus (GPIT MA 2126 an upper molar, and GPIT MA 2123 a lower molar) and two smaller taxa with thicker molar enamel.

A right $\mathrm{m} / 3$ from Melchingen (GPIT MA 2123) falls into the metric range of variation of the smaller species of Griphopithecus (G. alpani) from Pasalar (Turkey) (Andrews et al., 2008; Tekkaya, 1974) and like it, has strongly inclined buccal cusp walls, but its enamel seems to be thinner than is usual in this genus. It is here included in Dryopithecus fontani along with the upper molar GPIT MA 2126.

The second of these taxa, Neopithecus brancoi, is comparable in dimensions and most details of morphology to the holotype of Sivapithecus occidentalis Villalta \& Crusafont (1944), and that of Rahonapithecus sabadellensis Crusafont \& Hürzel- er (1961) (a nomen nudum according to Simons \& Pilbeam, 1965) and/or Anoiapithecus brevirostris Moyà-Solà et al. (2009b). The same taxon is represented by two teeth from Melchingen (GPIT MA 2127 and GPIT MA 2125) (Branco, 1898) the first of which was identified as an M1/ of Ramapithecus punjabicus by Simons \& Pilbeam (1965). Its lingual and buccal walls are almost vertical, its enamel is thick and its dimensions (10.2 x $11.2 \mathrm{~mm})$ are compatible with identification as Neopithecus. This tooth is therefore more likely to be an upper molar of Neopithecus brancoi than of Ramapithecus (which was in any case based on female specimens of Sivapithecus).

The third taxon in the Swabian Alb is represented by a lower molar (GPIT MA 2122) which resembles those of Hispanopithecus laietanus.

The SMNS collection from the Swabian Alb (Fig. 20) comprised four isolated molars to which we now add an upper central incisor, an upper male 
canine and an upper third premolar. The four molars in Stuttgart comprise at least three taxa, three possessing thin enamel with affinities to Dryopithecus, the other with thicker enamel.

In detail, the debate about the German hominoids is extremely complex. The study of German, Austrian and Hungarian fossil hominoids has experienced alternating and contradictory trends of what might loosely be termed splitting and lumping. But unthinkingly calling the researchers who named new genera and species "splitters" does them and science a disservice. Taking into account the context of the studies at the time that they were carried out, researchers such as Abel $(1901,1902)$ and Schlosser $(1901,1902)$ did an excellent job. They were endeavouring to understand the meaning of the morphometric variation that they observed in the sample, and they concluded that there was a high diversity of hominoid taxa in the region during the Miocene. Despite the limited number of specimens available they felt unable to shoehorn all the variation that they observed into a single taxon, or even into two or three. The naming of new genera and species was thus, to a certain extent, justified, although there is undoubtedly an element of synonymy present or at least of contradictory sorting of fossils.

Not counting the holotype tooth of Neopithecus brancoi, the rest of the teeth from the Swabian Alb have been attributed to the following species Dryopithecus rhenanus Pohlig (1895) by Schlosser $(1901,1902)$ and Gregory $(1916)$ and to Dryopithecus suevicus by Koken (1905) but without a holotype being designated. Abel (1919) proposed a name change to Dryopithecus germanicus because he believed that the species name rhenanus should apply only to the Eppelsheim femur, but he also neglected to nominate a holotype. Remane (1921) returned the fossils to Dryopithecus rhenanus, but Glaessner (1931) disagreed with this name change, and selected two specimens to illustrate as Dryopithecus germanicus (Branco 1898, Figs 1-1 and 2-1) that differed from the rest of the Swabian Alb specimens, the two specimens being thick enamelled and the lower molar with sloping buccal walls (here attributed to Dryopithecus). Authors subsequent to Simons \& Pilbeam (1965) have generally attributed all the specimens to Dryopithecus brancoi, by which means the morphological and metrical differences demonstrated by previous authors were swept away and forgotten. Ironically, the "lumping" has caused far more complexity than the "splitting" did, as researchers since 1965 , have tried to compare fossils from other sites with a Swabian Alb chimera comprised of at least three taxa.

The trend towards lumping, which began in earnest with the publication of Simons \& Pilbeam (1965) has proved, in retrospect, to be biologically unrealistic, and therefore untenable. The aim of their publication was to simplify the taxonomy of the Miocene apes of the world, but it started out from the premise that because extant apes were of low diversity, then so must have been those of the Miocene. But a simple consideration of biogeography renders such a premise unlikely. Extant apes occur only within $10^{\circ}$ latitude of the Equator, in Central Africa and Southeast Asia, whereas at the time of the Simons \& Pilbeam (1965) synthesis, it was known that fossil apes had been found as far north as $49^{\circ}$ of latitude in Germany, and from Spain in the west to China in the East, passing via India, spanning an area more than 10 times greater than the range of living hominoids, gibbons included. It would seem that such a huge area would be unlikely to have contained only three or four genera of apes (Dryopithecus, Ramapithecus, Gigantopithecus, and Oreopithecus). Not only that, but the fossils classified into Dryopithecus by Simons and Pilbeam (1965) spanned more than 10 million years of geological time. The authors also believed that the ancestors of the Orang Utan, the Chimpanzee and the Gorilla could be traced back to separate Early Miocene species of Dryopithecus (Proconsul) from East Africa, and the ancestors of humans back to the Middle Miocene Ramapithecus.

Le Gros Clark \& Leakey (1951) reported that the holotype of Neopithecus brancoi closely resembles in its dimensions and appearance that of Proconsul africanus (in their paper, specimens belonging to at least four genera were included in Proconsul africanus: Proconsul, Rangwapithecus, Nyanzapithecus and Turkanapithecus (Pickford et al., 2010). However, the morphological differences between the Kenyan and German specimens are clear (less coarsely wrinkled enamel, divergent cusp layout and a better developed buccal cingulum in Proconsul-cingulum absent in Neopithecus).

The simplification proposed by Simons \& Pilbeam (1965) was an inappropriate application of Occam's razor, and it did not realistically take into account the observed morphometric variation demonstrated in the literature. Furthermore, their study was carried out with a peculiar notion of variation in extant apes and hominids in mind. The 
search for early human ancestors was in full swing at the time of their research, and the main protagonists in this endeavour consistently interpreted the remains of female fossil Miocene apes to represent early hominids: Kenyapithecus by Leakey (1962); Ramapithecus by Simons \& Pilbeam (1965, 1978b): whereas the males of the same species were classified as apes (Pickford and Chiarelli, 1986). Thus the males of Kenyapithecus were incorrectly classified as Proconsul (Leakey, 1962) and females of Sivapithecus were identified as Ramapithecus (Simons \& Pilbeam, 1965, 1978a, 1978b). Under this scheme, the sorting of fossils into taxonomic groups was carried out within a framework that did not take into account the kind of variation present in extant apes (sexual dimorphism in particular was underplayed or misunderstood); the result was that males and females of single species were classified as distinct taxa within two separate families of Hominoidea (at the time Pongidae and Hominidae) at the same time that a high diversity of fossil apes was shoehorned into a single genus (in early papers, even Proconsul and Sivapithecus were classified in Dryopithecus). These authors even proposed that "D. africanus and D. laietanus might be recognised as pygmy varieties of $D$. nyanzae and $D$. sivalensis" (Simons \& Pilbeam, 1965). Material attributed to these two "species" by Simons \& Pilbeam (1965) is currently arranged into three genera, Proconsul, Hispanopithecus and Sivapithecus. The Simons \& Pilbeam (1965, 1978a, 1978b) approach to Miocene hominoid taxonomy was thus deeply flawed, not only from a biogeographic perspective, but also from the point of view of geochronology and of variation in closely related organisms. Nevertheless, the publication had an enormous influence, especially in the Anglo-Saxon world, and it affected interpretations of fossil hominoids for more than two decades (Pickford, 1985) with echoes to recent times (Begun, 2002).

The tendency to lump hominoid taxa initiated by Simons \& Pilbeam (1965) has continued among some researchers to this day (Martin \& Andrews, 1993) with several authors prone to interpret the variation demonstrated to occur among the European Miocene hominoids, as variation within a very limited number of taxa - in the case of Germany and neighbouring countries, only two genera (Dryopithecus and Griphopithecus) (this paper is not concerned with the pliopithecoids, which are generally accepted as having enjoyed a high diversity in Europe, although, in this case as well, there are those who accept a high diversity, and those who do not). As in many scientific endeavours, improvements of the quality and quantity of data available, have led to some degree of clarification. In this case the demonstration that there is indeed a high taxonomic diversity among European hominoids has come from excavations carried out in the VallèsPenedès Basin, Catalonia, northeastern Spain, where relatively complete fossils have been recovered, which show that there are at least four genera of Miocene large hominoids in the region (Dryopithecus, Hispanopithecus, Pierolapithecus, Anoiapithecus) (Casanovas-Vilar et al., 2008; Moyà-Solà et al. 2004, 2009a, 2009b). The variation documented in Vallès-Penedès is slightly more than the degree of variation documented in Germany a century ago (Abel, 1901, 1902; Schlosser, 1901, 1902) with Dryopithecus, Neopithecus and Griphopithecus, leaving aside Paidopithex and Austriacopithecus which were based on post-cranial remains (Pohlig, 1895; Ehrenberg, 1938) and Rhenopithecus Von Koenigswald (1956) which was based on an incomplete lower molar of presently unknown affinities (type species Semnopithecus eppelsheimensis Haupt, (1935)) although it is probably not a monkey as thought by its creator.

Some recent summaries of the history of study of European hominoids are inaccurate. In his taxonomy, Begun (2002) listed Dryopithecus brancoi Schlosser, 1901 (without brackets around the author's name). This is not correct: Abel (1902) created the genus Neopithecus for the species Anthropodus brancoi Schlosser, 1901, the genus name Anthropodus Schlosser, 1901, being preoccupied by Anthropodus Lapouge, 1894. Thus the correct listing is Neopithecus brancoi (Schlosser, 1901). Schlosser $(1901,1902)$ examined the status of the holotype of Neopithecus brancoi, and concluded that it could not belong to Dryopithecus, hence the decision to erect a new genus for it. Thus, Begun's version of the history not only contravened the conventions of systematics, but also inaccurately summarised Schlosser's contribution to the nomenclature of European hominoids. Begun (2002) made the same error with Dryopithecus laietanus Villalta \& Crusafont, 1944, which was originally described as Hispanopithecus laietanus: listed as Dryopithecus laietanus, the authors' names should be in brackets.

What remains to be done is to determine whether any of the old names proposed for other European hominoids represent the same taxa as 
the recently named Spanish forms. The nomenclatural history of the hominoids from the Swabian Alb and other North European sites is complicated, and reflects the difficulties of analysing isolated teeth and post-cranial bones. Nevertheless, researchers involved in these studies, including Schlosser (1901, 1902) and Abel (1901, 1902) were experienced palaeontologists who had studied many groups of mammals, and thus had a well developed appreciation for the kind and degree of variation that can be encompassed by mammalian species. Thus, when Abel (1919) proposed the name Dryopithecus germanicus for part of the Swabian Alb hominoid sample, he was articulating the observation that it couldn't all be maintained in a single species Neopithecus brancoi. Likewise, Kretzoi $(1969,1974,2002)$ felt unable to classify all the Rudabánya hominoid fossils into a single taxon. Ditto for the Spanish material that passed through the hands of Crusafont (1958, 1964; Villalta \& Crusafont, 1944). Despite the efforts of some palaeoanthropologists to criticise these pioneering studies by lumping everything into Dryopithecus, more recent discoveries have vindicated the results of the pioneers.

In contrast to the assessment of fossils carried out by generalist palaeontologists such as Abel and Schlosser, palaeoanthropologists, who generally have little or no experience with groups of mammals other than hominoids, have tended to lump together diverse taxa by accepting much greater ranges of morphological and metric variation in their "species" than mammalian palaeontologists have been prone to do. With the recent discovery of much more informative hominoid fossils in Spain, Turkey, Hungary, East Africa, the Indian Subcontinent, Thailand and China, the approach taken by generalist palaeontologists such as Abel, Crusafont, Kretzoi and Schlosser have, in general, been closer to the mark than any of the classifications by "lumpers". Many of the names declared by Simons \& Pilbeam (1965) to be synonyms of Dryopithecus, have had to be been resurrected, including Sivapithecus, Indopithecus, Griphopithecus, Proconsul, and Hispanopithecus. One that is long overdue is Neopithecus, which predates all the others save Dryopithecus Lartet (1856), Paidopithex Pohlig (1895) and Pliohylobates Dubois (1897) (the last name is a synonym of Paidopithex as it is based on the same fossil specimen as the former). In contrast, Ramapithecus which was once widely believed to be valid, especially following the revision by
Simons \& Pilbeam (1965) is today considered to be a synonym of Sivapithecus.

The holotype of Neopithecus brancoi, an isolated $\mathrm{m} / 3$ from Salmendingen (GPIT MA 2124), was originally named Anthropodus brancoi by Schlosser (1901) and then Neopithecus brancoi by Abel (1902), the generic name Anthropodus Lapouge, 1894, being preoccupied. Remane (1921) transferred the specimen toDryopithecus rhenanus, an attribution not accepted by Abel (1931) who classified it as Dryopithecus brancoi. Hürzeler (1954) considered it to belong to Pliopithecus, but it was reinstated as a Dryopithecus by Szalay \& Delson (1979) and subsequently by Begun (2002) who considered it to be identical with the Hungarian Rudapithecus hungaricus, which, according to him, thus fell into synonymy with Dryopithecus brancoi. For a while Spanish material was attributed to $D$. brancoi by Szalay \& Delson (1979)(specimens originally described as Hispanopithecus laietanus by Villalta \& Crusafont (1944) and Rahonapithecus sabadellensis by Crusafont \& Hürzeler (1961), the latter declared to be a nomen nudum by Simons \& Pilbeam, 1965). Begun (1992a) removed the Spanish specimens from $D$. brancoi, and referred the Rudabánya fossils to it. In the meantime, Thenius (1982) and Zapfe (1989) attributed some isolated teeth from Mariathal and Götzendorf in Austria, to Dryopithecus brancoi, but some of the fossils (an upper incisor from Götzendorf, for example) are more likely to represent Anapithecus hernyaki, and the status of the others remains unclear, although it has been suggested that some or all of them are likely to belong to pliopithecoids rather than to dryopithecines (Andrews et al., 1996). Mention should be made of the species Rudapithecus carinthiacus (nov. comb.) from St Stefan, Austria, (Mottl, 1957) which is close morphometrically to the Rudabánya specimens, but which differs from classic Dryopithecus fontani in having a distinct protoconid in the $\mathrm{p} / 3$ which is separated at its apex from the metaconid. This $\mathrm{p} / 3$ morphology predicts the derived morphology present in Oreopithecus from Italy. None of the Spanish hominoid fossils possesses morphology comparable to the $\mathrm{p} / 3$ of $R$. carinthiacus.

In summary, since 1901, the small sample of Swabian Alb hominoid fossils has been attributed to a bewildering variety of species. In chronological order the following names have been proposed for some or all of the material. Anthropodus brancoi Schlosser (1901), Neopithecus brancoi (Schlosser, 
1901), Dryopithecus rhenanus (Pohlig, 1895), Dryopithecus fontani Lartet (1856); Dryopithecus suevicus Koken (1905) (catalogue name only without diagnosis or designation of type material, but discussed in the literature by Simons \& Pilbeam, 1965), Dryopithecus germanicus Abel (1919), Dryopithecus brancoi (Schlosser, 1901), and Ramapithecus punjabicus (Pilgrim, 1910) (Simons \& Pilbeam, 1965).

My current assessment of the German fossils indicates that there are least five taxa present, not counting the Engelswies tooth attributed to Griphopithecus sp. by Heizmann \& Begun, (2001).

1. Neopithecus brancoi occurs at Salmendingen (the type locality) and Melchingen.

2. Dryopithecus fontani is present at Wissberg, Melchingen, Ebingen and Salmendingen.

3. Hispanopithecus laietanus occurs at Trochtelfingen and Melchingen.

4. Udabnopithecus garedziensis (a synonym of Dryopithecus crusafonti) or a related form is present at Neuhausen.

5. Anoiapithecus brevirostris or a closely related form is present at Neuhausen.

I consider that there are at least two taxa of dryopithecines at Rudabánya, Hungary, as originally proposed by Kretzoi $(1969,1974)$ and there are three at Pasalar, Turkey: Andrews et al. (1990) and Kelley et al. (2009) mention two species at Pasalar but their metric data reveal the presence of three (author's interpretation of their results). There are four taxa in Spain (Moyà-Solà \& Köhler, 1995; Moyà-Solà et al., 2009a, 2009b).

The history of study of Spanish hominoids is almost as complicated as that of the German specimens (Moyà-Solà et al., 2009a, 2009b). The first fossil ape found in the country was a left mandible from Seu d'Urgell (Lérida = Lleida) for a long time attributed to Dryopithecus fontani (Simons \& Pilbeam, 1965; Szalay \& Delson, 1979; Vidal, 1913; Woodward, 1914) but later transferred to Dryopithecus crusafonti Begun (1992, 2002). The rich deposits in the Vallès-Penedès started yielding fossil hominoids during the 1940's (Villalta \& Crusafont, $1941,1944)$ although a tooth found in the 1920's was for many years misidentified as that of a suid until 1999 (Van der Made \& Ribot, 1999). Over the years several genera and species have been reported from the region, including Hispanopithecus laietanus (type locality La Tarumba but best known from Can Llobateres), generally considered to
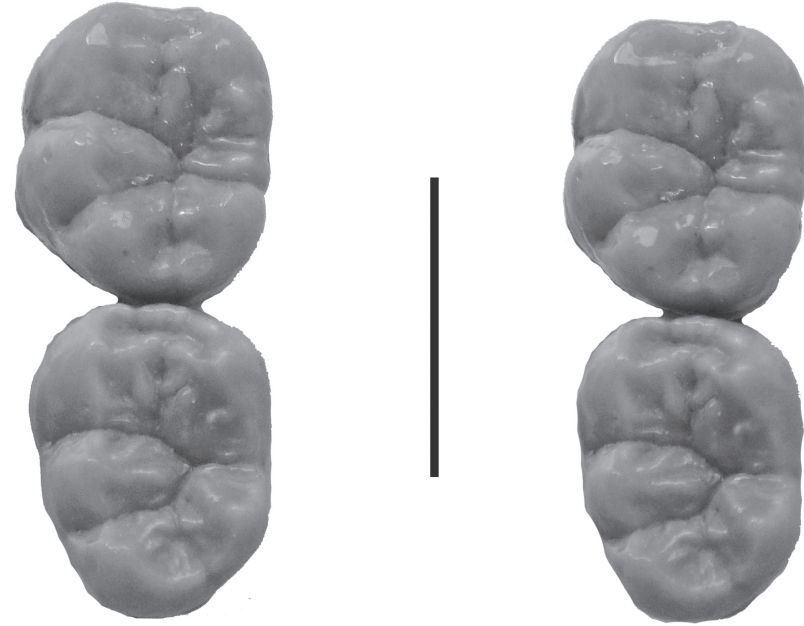

Fig. 17.-Type specimen of Sivapithecus occidentalis, IPS 182627, from Can Vila, stereo occlusal view of original fossils (scale: $10 \mathrm{~mm})$.

belong to Dryopithecus (Moyà-Solà \& Köhler, $1995)$ although the same authors have recently resurrected the genus Hispanopithecus (Moyà-Solà et al., 2009a). Rahonapithecus sabadellensis was declared to be a nomen nudum by Simons \& Pilbeam (1965). Sivapithecus occidentalis Villalta \& Crusafont (1944) was based on a specimen (IPS 1827, left $\mathrm{m} / 2-\mathrm{m} / 3$ ) from Can Vila (Els Hostalets de Pierola). Dryopithecus piveteaui Crusafont \& Hürzeler (1961) from Can Llobateres is based on IPS 1822 (old catalogue $\mathrm{N}^{\circ}$ IPS 11) a left $\mathrm{m} / 3$ or perhaps an $\mathrm{m} / 2$ (Harrison, pers. comm.) but the species was never formally described, and is thus a nomen nudum. Dryopithecus crusafonti Begun (1992a) was based on the material from Can Ponsic and Lleida. Recently, Moyà-Solà et al. (2004, 2009b) have erected two new genera of Miocene apes from the Vallès-Penedès, near Barcelona, Spain: Pierolapithecus catalaunicus and Anoiapithecus brevirostris, both from sites at Els Hostalets de Pierola, where Dryopithecus fontani also occurs (Moyà-Solà et al., 2009a).

\section{The Neopithecus problem}

The holotype specimen of Neopithecus brancoi, from Salmendingen (Schlosser, 1901; Abel, 1902) is a left $\mathrm{m} / 3$ which closely resembles the specimen (IPS 1827) from Can Vila, Els Hostalets de Pierola, Spain, the holotype of Sivapithecus occidentalis Villalta \& Crusafont (1944). Not only is the type speci- 

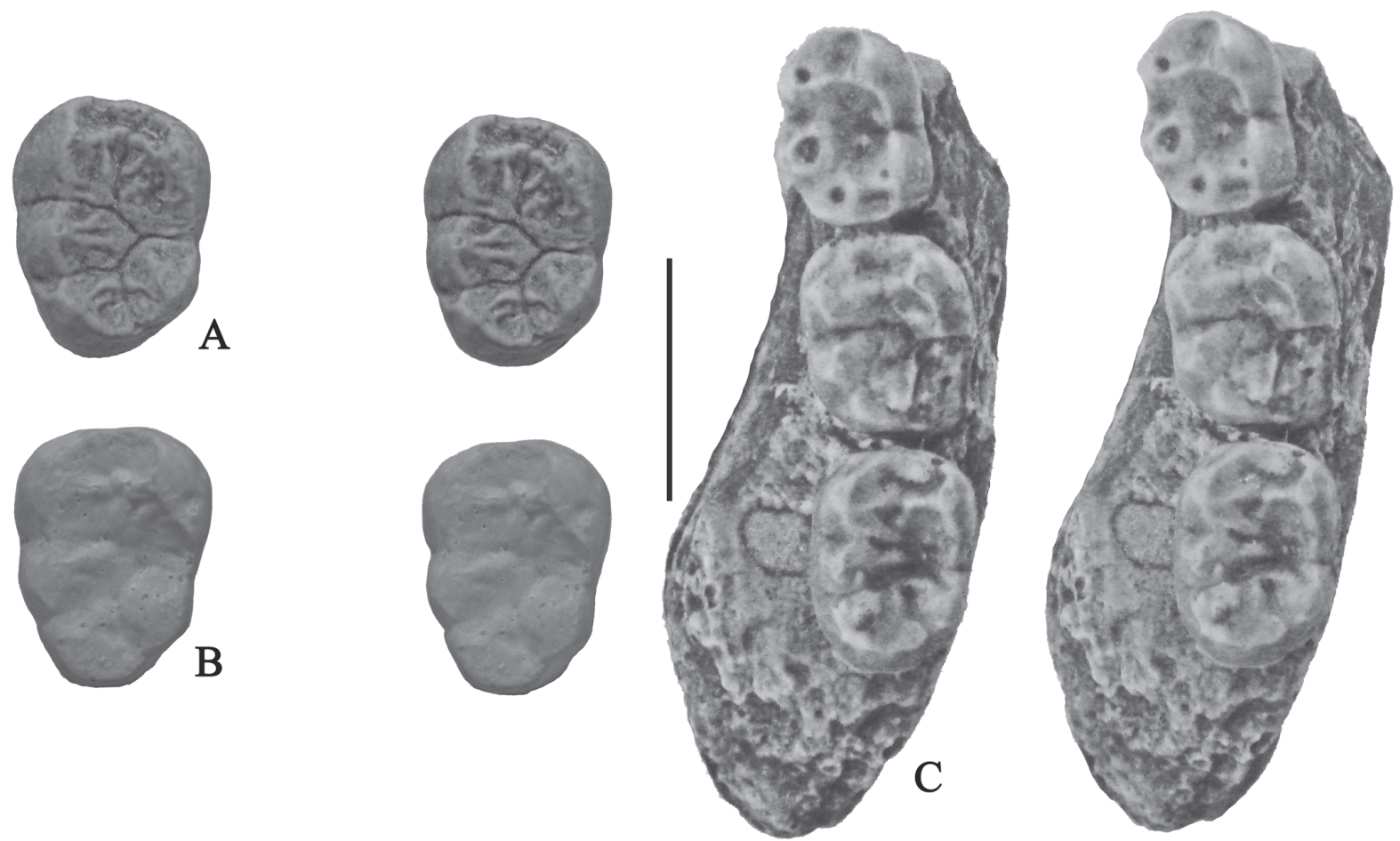

Fig. 18.-Comparison of casts of left m/3s, A) IPS 1827, part of holotype of Sivapithecus occidentalis from Can Vila, Spain, B) Salmendingen, Germany, holotype of Neopithecus brancoi, and C) IPS 1802, Rahonapithecus sabadellensis, right mandible with m/1$\mathrm{m} / 3$ from Can Llobateres, Spain, currently attributed to Hispanopithecus laietanus (mirror image) stereo occlusal views (scale: $10 \mathrm{~mm}$ ).

men of $N$. brancoi $(10.8 \times 8.1 \mathrm{~mm})$ similar in dimensions to the Spanish tooth $(10.9 \times 8.6 \mathrm{~mm})$, but it is close in morphology to it, allowing, of course, for the differences in wear. In particular the hypoconulid is distally positioned relative to the position of the entoconid, unlike in the genus Dryopithecus in which the hypoconulid is not so distally positioned, being almost opposite the entoconid. In addition the buccal and lingual walls of the lower molars are almost vertical in both specimens. The roots of the Salmendingen specimen are short and stout, similar to the preserved parts of the specimen from Els Hostalets, the distal root being rounded triangular in section and slanting distinctly distally, in contrast to the roots of $\mathrm{m} / 3 \mathrm{~s}$ in Dryopithecus fontani which are longer, more ovoid or rectangular in section, mesio-distally compressed and transversely oriented and in general do not slope so strongly to the rear. Furthermore, the Salmendingen tooth is moderately worn (Fig. 17) but shows no sign of dentine exposure, indicating the presence of a thick enamel cap, as in "Sivapithecus" occidentalis, the type specimen of which is unworn, and the occlusal enamel thickly wrinkled (Fig. 17). The only significant dif- ference between the Salmendingen and Can Vila teeth is the mesio-distally narrower mesial fovea in the Spanish specimen (Fig. 18). The lower $\mathrm{m} / 3$ of Rahonapithecus sabadellensis (Crusafont \& Hürzeler, 1961) a nomen nudum according to Simons \& Pilbeam (1965) is also similar to the holotype of Neopithecus brancoi, its mesial fovea being as broad mesio-distally as that of the Salmendingen tooth, and its roots short and stout. It is likely that the minor morphological differences expressed in the $\mathrm{m} / 3 \mathrm{~s}$ of Sivapithecus occidentalis, Rahonapithecus sabadellensis and Neopithecus brancoi represent intra-specific variation. On this basis all three are considered to belong to a single species Neopithecus brancoi. Currently available evidence indicates that Anoiapithecus brevirostris is likely to represent a distinct genus and species (no $\mathrm{m} / 3$ is yet known for this taxon), although it should be noted that the Salmendingen $\mathrm{m} / 3$ occludes well with the M3/ of $A$. brevirostris. It is noted that the cast of the Can Vila specimen illustrated by Begun (2009) appears to have suffered distortion and abrasion of the prominences, and does not give a reliable impression of its morphology. 


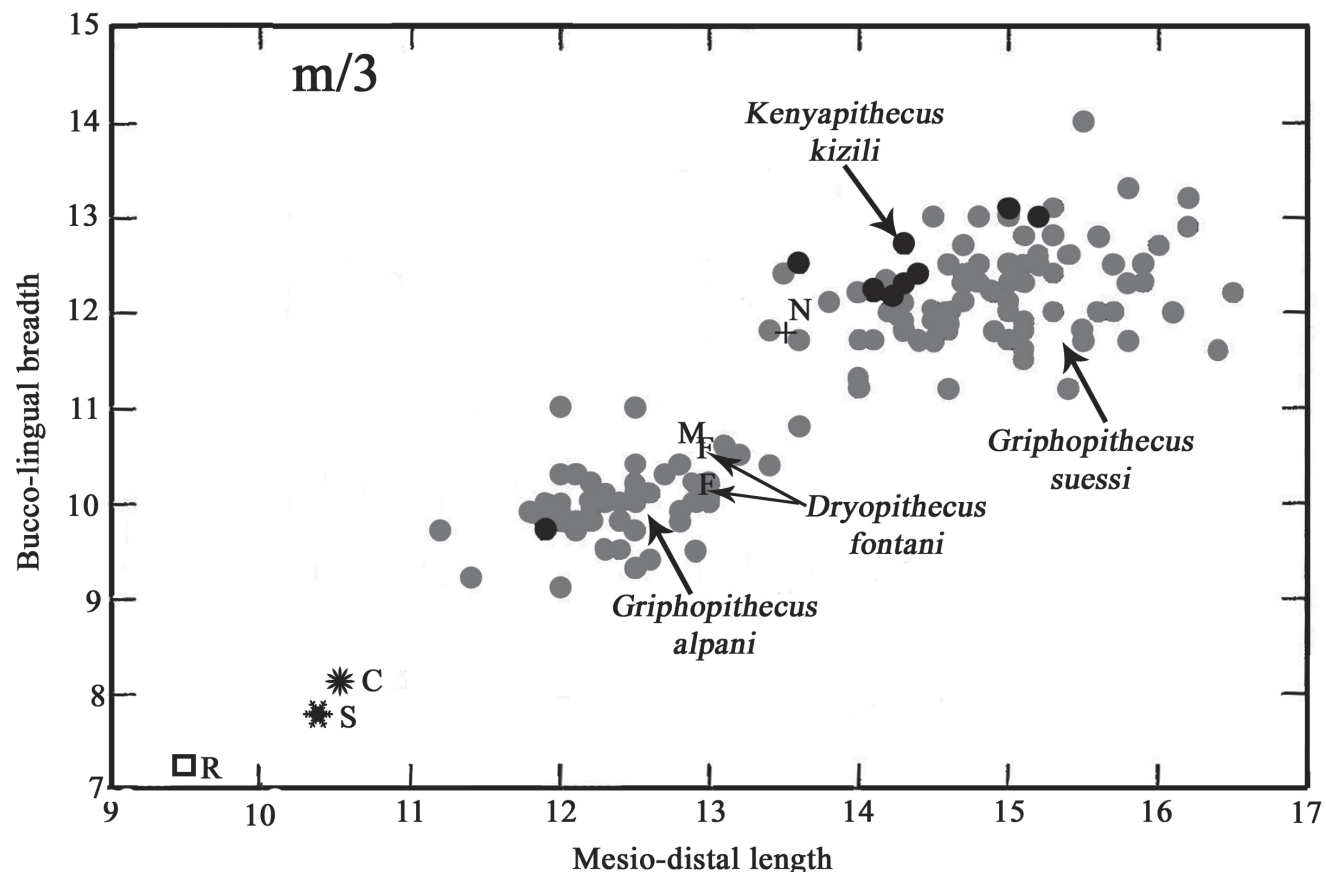

Fig. 19._Bivariate plots of Pa_alar lower third molars, and some specimens from Germany and Spain. (C - IPS 1826, Can Vila (Neopithecus brancoi = holotype of Sivapithecus occidentalis); F - Dryopithecus fontani (Bordeaux specimens); M - Melchingen, (Griphopithecus sp.); +N - Neudorf (Griphopithecus suessi referred m/3); R - IPS 1802 (Neopithecus brancoi = holotype of Rahonapithecus sabadellensis); S - Salmendingen (holotype of Neopithecus brancol). Pa_alar data from Humphrey \& Andrews (2008).

Table 7.-Summary of fossil hominoids present in the Swabian Alb and the Rhine Graben

\begin{tabular}{ll}
\hline Dryopithecus fontani & Melchingen, Ebingen, Salmendingen, Wissberg \\
\hline Neopithecus brancoi & Salmendingen, Melchingen \\
\hline Hispanopithecus laietanus & Trochtelfingen, Melchingen \\
\hline $\begin{array}{l}\text { Dryopithecus crusafonti* (or its possible senior synonym } \\
\text { Udabnopithecus garedziensis). }\end{array}$ & Neuhausen \\
\hline Anoiapithecus brevirostris* & Neuhausen \\
\hline
\end{tabular}

* One or other of these species could be a junior synonym of Neopithecus brancoi. The Engelswies tooth attributed to Griphopithecus is not counted in this total.

The taxa Pierolapithecus catalaunicus and Dryopithecus fontani are too large for them to represent the same species as Neopithecus brancoi (Fig. 19). The $\mathrm{m} / 3$ in mandible and an isolated $\mathrm{m} / 3$ of Dryopithecus fontani housed in the Natural History Museum in Bordeaux measure $13.0 \times 10.2 \mathrm{~mm}$ and $13.0 \mathrm{e}$ x $10.5 \mathrm{~mm}$ respectively (own measurements), whereas the homologous measurements of the $\mathrm{m} / 3$ of Neopithecus brancoi are 10.8 x $8.1 \mathrm{~mm}$. No m/3 of $P$. catalaunicus is known, but judging from the other remains, it was smaller than $D$. fontani (see body weight estimates by Moyà-Solà et al., 2004, 2009) but would have been appreciably larger than N. brancoi.

The Can Vila $\mathrm{m} / 3$ is unworn, the Salmendingen tooth is in medium wear, but the cusp proportions and the wrinkling that is discernible in the Salmendingen tooth are similar to those of the Spanish tooth. The main difference between these specimens concerns the positioning of the crests that run towards each other from the metaconid and protoconid, which comprise the distal wall of the 
mesial fovea. The $\mathrm{m} / 3$ formerly attributed to Rahonapithecus sabadellensis is like that from Salmendingen. Note in particular the distally positioned hypoconulid in all three teeth and the presence of a tuberculum sextum; in Dryopithecus the hypoconulid is relatively further forwards, almost opposite the entoconid.

\section{Comparison of Neopithecus brancoi with Rudapithecus carinthiacus}

The holotype of Neopithecus brancoi is unlike the m/3 in RUD 17 from Rudabánya, in which the crown is foreshortened rather than elongated, and in which the entoconid and hypoconulid are reduced, such that the crown is almost triangular in occlusal outline, rather than forming a mesio-distally elongated rectangle with rounded distal margin. The enamel appears to be thin in the Rudabánya species (Begun \& Kordos, 1993). A second $\mathrm{m} / 3$ from Rudabánya (RUD 16) has the hypoconulid in a forward configuration, as in Dryopithecus fontani, and it too differs from the type specimen of Neopithecus brancoi. From this evidence, we conclude that attribution of the Rudabánya fossils to the species Neopithecus brancoi is no longer sustainable, and Begun (2009) has come to the same conclusion independently. It should be noted here that the hominoid $\mathrm{p} / 3 \mathrm{~s}$ from Rudabánya possess tall protoconids which are separated at their apices from the metaconids. This morphology also occurs in the type specimen of Dryopithecus carinthiacus from St Stefan, Austria (Mottl, 1957) but differs from the morphology found in Dryopithecus fontani (Gaudry, 1890; Harlé, 1898, 1899) and the species Hispanopithecus laietanus and Dryopithecus crusafonti, in which the protoconid crest is well developed, but is not detached from the metaconid apically. Thus, the Rudabánya fossils are better accommodated in the species Rudapithecus carinthiacus (comb. nov.) than in Neopithecus brancoi. We note, incidentally, that the $\mathrm{p} / 3$ morphology in the St Stefan and Rudabánya hominoids would make a suitable precursor for the morphology observed in Oreopithecus bambolii.

\section{Neuhausen and Rudapithecus carinthiacus (comb. nov.)}

It is not possible to compare the Neuhausen teeth with Rudapithecus carinthiacus (Mottl,
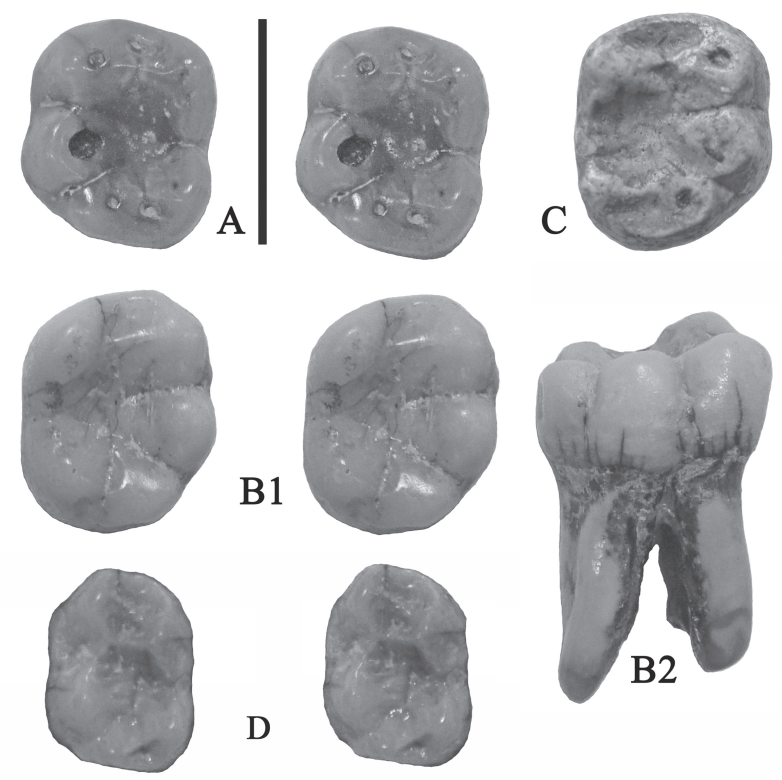

D

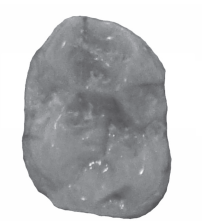

B2
Fig. 20.-Lower molars from Germany curated at the SMNS, attributed to Dryopithecus fontani. A) SMNS 14513 , left $\mathrm{m} / 1$ or $\mathrm{m} / 2$ from Ebingen, stereo occlusal view, B) SMNS 43459 right $\mathrm{m} / 1$ or $\mathrm{m} / 2$ from Salmendingen, B1) stereo occlusal view, B2) buccal view, C) BSPG 1952 I 102 cast of right $\mathrm{m} / 1$ or $\mathrm{m} / 2$ from Wissberg, Gau-Weinheim, occlusal view, D) SMNS 43460, left $\mathrm{dm} / 4$ from Salmendingen stereo occlusal view (scale: $10 \mathrm{~mm}$ ).

1957) because the latter species is known only from a mandible from St Stefan, Austria. This mandible was declared to belong to $D$. brancoi by Szalay \& Delson (1979) and by Begun (1992a) based on comparisons with the Salmendingen holotype of N. brancoi, but Andrews et al. (1996) thought that the latter tooth might represent a pliopithecoid instead. The latter hypothesis can be definitively rejected as can its attribution to the genus Dryopithecus.

\section{The presence of Dryopithecus in Germany}

Some of the isolated molars from Germany probably do belong to Dryopithecus fontani, including a specimen from Wissberg near Gau-Weinheim (Von Koenigswald, 1952), a tooth from Ebingen (left m/1 similar to Dryopithecus fontani) (Branco, 1898), two from Melchingen (GPIT MA 2126, a left M2/ and GPIT MA 2123, a right $\mathrm{m} / 3$ ), and two teeth from Salmendingen (right $\mathrm{m} / 2$ on the basis of the root morphology and the presence of a posterior contact facet, not an $\mathrm{m} / 3$ as reported by Jäger, $1850)$, and a left $\mathrm{dm} / 4$, sometimes attributed to Anapithecus hernyaki (Begun, 2002). 

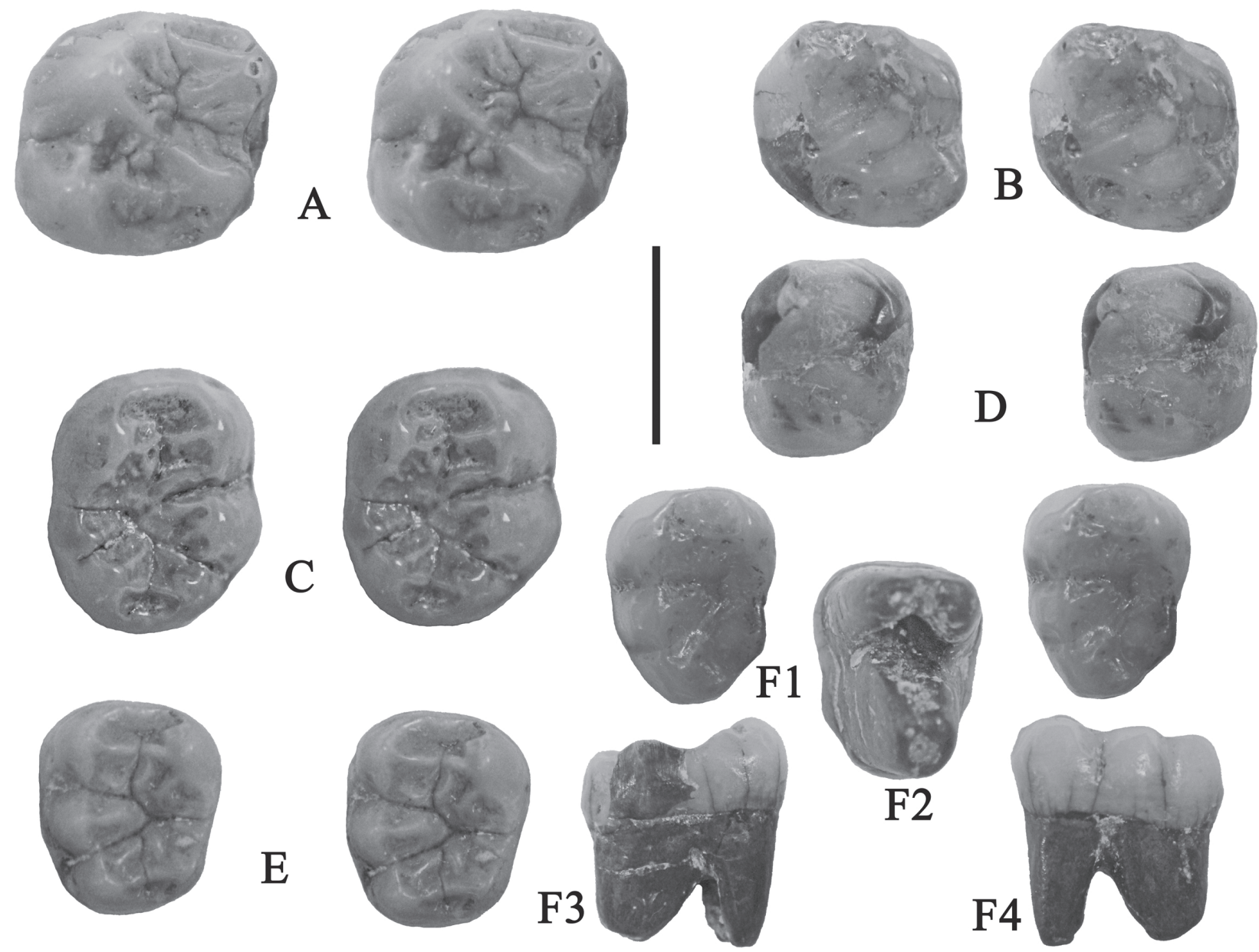

Fig. 21.-Hominoid teeth from Swabian Alb Miocene Bohnerz, housed at Tübingen University. A) GPIT MA 2126, left M2/ from Melchingen, B) GPIT MA 2127, right M2/ (or M1/) from Melchingen, C) GPIT MA 2123, right m/3 from Melchingen, D) GPIT MA 2125, right $\mathrm{m} / 2$ or $\mathrm{m} / 1$ from Melchingen, E) GPIT MA 2122, left m/2 (or m/3?) from Trochtelfingen, F) GPIT MA 2124, holotype left m/3 of Neopithecus brancoi. Stereo occlusal images save for F2, radicular, F3, lingual, and F4, buccal views. (Scale: $10 \mathrm{~mm}$ ).

For some authors (Andrews et al., 1996) the German hominoid molars on their own provided insufficient evidence to resolve the issue whether Dryopithecus fontani was present in the country or not, but some of the specimens are probably of this species. Teeth that are confidently attributed to Dryopithecus fontani are SMNS 14513, a left m/1 or $\mathrm{m} / 2$ (10.6 x 9.3) from Ebingen, BSPG 1952 I 102 (cast), a right $\mathrm{m} / 1$ or $\mathrm{m} / 2(10.8 \times 9.4 \mathrm{~mm})$ from Wissberg, near Gau-Weinheim (Fig. 20) and GPIT MA 2126, a left M2/ from Melchingen (Fig. 21A).

\section{Griphopithecus in Germany}

The debate about Griphopithecus is almost as complicated as that concerning Dryopithecus and
Neopithecus. Recently clarified by Holec \& Emry (2008) who summarised the history of this taxon, it was pointed out that previous authors (starting with Glaessner, 1931) were in error in declaring the type species, Griphopithecus suessi, to be a junior synonym of Dryopithecus darwini. Under the circumstances of this case, it is not possible to eliminate the type species of the genus without at the same time eradicating the genus. Thus, the decision to call the Sandberg species Griphopithecus darwini by Andrews et al. (1996) is not sustainable. If Griphopithecus is a valid genus, then the species has to be called Griphopithecus suessi Abel (1902). But if Griphopithecus and Sivapithecus are the same genus as maintained by Simons \& Pilbeam (1965), then the Indian form must be called Griphopithecus Abel (1902), because it has priority over 
Sivapithecus Pilgrim (1910). However, the morphological differences between the Slovakian and Indian hominoids suggests that they belong to different genera, but for an opposite view, read Kay (1982).

SMNS 43459, a right $\mathrm{m} / 1$ or $\mathrm{m} / 2(11.8 \times 10.1$ $\mathrm{mm}$ ) from Salmendingen, appears to have thicker enamel than is usual in Dryopithecus fontani, but is kept in this species on the basis of its crown morphology (Fig. 20B). Further study is warranted, but it is clear that the enamel of Pierolapithecus catalaunicus and Anoiapithecus brevirostris is thicker than that of Dryopithecus fontani (Alba et al., 2010).

\section{Anapithecus in Germany?}

Whether the pliopithecoid Anapithecus is present in the Bohnerz of the Swabian Alb was debated until recently, the tooth attributed to Anapithecus hernyaki by Begun (2002) being interpreted as a deciduous molar of Dryopithecus by Harrison (1991). The presence of an oblique cristid traversing the anterior fovea, and the trigonid narrower than the talonid suggest that this tooth is a deciduous molar, and not a permanent molar of a large pliopithecoid (Moyà-Solà pers. comm. 2010). As a deciduous fourth molar, it is evidently from a large species of ape, perhaps as big as Dryopithecus fontani or Pierolapithecus catalaunicus. Thus, there is no dental evidence in support of the presence of Anapithecus in the Swabian Alb deposits of Germany. However, the femur described as Paidopithex rhenanus is likely to represent a large pliopithecoid rather than a small, gracile limbed hominoid (see below).

\section{The validity of Udabnopithecus garedziensis?}

Udabnopithecus garedziensis was published by Burtschak-Abramovitsch \& Gabachvili (1946) on the basis of associated $\mathrm{P} 4 /(6.9 \times 10.1 \mathrm{~mm})$ and M1/ (9.0 x $10.7 \mathrm{~mm})$ from Udabno (Desert) in Georgia. The specimen resembles the Can Ponsic fossils for which Begun (1992a) erected the species Dryopithecus crusafonti in the belief that it was a member of this genus, and differed from $N$. brancoi. That the Can Ponsic specimens are not the same as Neopithecus brancoi is clear, not just from the point of view of dimensions, but also of morphology, but what has not been established is whether they differ metrically or morphologically from $U$. garedziensis. The concave profile of the buccal surface of the paracone of the P4/, the crystodont wear facets and the dimensions and morphology of the two teeth from Georgia indicate that they have a high probability of representing the same species, in which case the Can Ponsic fossils may well have to be called Udabnopithecus garedziensis rather than Dryopithecus crusafonti (the concave buccal profile of the upper premolars indicate that these species are unlikely to belong to the genus Dryopithecus).

\section{The Paidopithex problem}

Paidopithex rhenanus Pohlig (1895) currently represented only by the holotype femur which is far too small to belong to Dryopithecus fontani, the femur of this species from Spain being of an animal which weighed as much as $55 \mathrm{~kg}$ (Moyà-Solà et al., 2009a). It is even too small to belong to Anoiapithecus or Hispanopithecus, which are the smallest of the Spanish hominoids (Köhler et al., 2002). From this and from its gracile morphology we consider that it represents a pliopithecoid, possibly Anapithecus, which, if correct, would thus be a junior synonymy of Paidopithex.

The name Paidopithex rhenanus or derivatives of it (Dryopithecus rhenanus) have coloured interpretation of German fossil hominoids in various ways. The determination of the Eppelsheim femur as that of a pliopithecid rather than a dryopithecine means that none of the Swabian Alb or Rhine Graben hominoid molars at various times attributed to $D$. rhenanus belong to that taxon.

\section{The status of Dryopithecus suevicus and Dryopithecus germanicus}

The names Dryopithecus suevicus and Dryopithecus germanicus were proposed for the hominoids from the Swabian Alb, but no type specimens were designated. The collection of specimens from the various sites is now known to belong to several different taxa, and thus the concept of the species as applied to this collection created a chimera. The lack of type specimens means that both Dryopithecus suevicus and Dryopithecus germanicus are nomina nuda, and thus not available in formal taxonomy. 


\section{Identification of hominoid teeth from La Grive}

Although an upper incisor and an upper M3/ from La Grive St-Alban, France (Depéret, 1911), have been traditionally attributed to Dryopithecus fontani, it is clear that the teeth are close matches to the teeth in the type specimen of Pierolapithecus catalaunicus (Begun et al., 2006 -not Begun \& Ward, 2005 as cited by Begun, 2009). Begun (2009) took these resemblances to mean that Pierolapithecus was a junior subjective synonym of Dryopithecus, but a recently described maxilla of Dryopithecus fontani from Spain (Moyà-Solà et al., 2009a) reveals that there are marked differences between Pierolapithecus and Dryopithecus, not only dentally but also cranially. In contrast to Begun (2009) I therefore attribute the material from La Grive to Pierolapithecus catalaunicus. However, the issue of the teeth from La Grive is not closed, as Moyà-Solà et al. (2009a) concluded that the specimens belonged to Dryopithecus fontani.

\section{The affinities and inter-continental biogeography of European hominoids}

Begun (2002) has long held the view that Dryopithecus from Europe holds special significance as a potential ancestor from which African Apes and humans evolved - the Back-to-Africa hypothesis. In contrast, Moyà-Solà \& Köhler (1993, 1995, 1996) and Moyà-Solà et al. (2009a) saw closer resemblances between Dryopithecus and Pongo, than to African apes and humans, while Pickford \& Senut (2005) held the view that the resemblances between Dryopithecus and African apes was due to a Dryopithecus-like form which originated in Africa and then emigrated to Europe - the Out-of-Africa hypothesis. More likely is the hypothesis that from about $12 \mathrm{Ma}$ to about $8 \mathrm{Ma}$, southern Europe and Africa comprised an enlarged proto-Ethiopian biogeographic realm in which many vertebrate lineages could disperse relatively freely over this vast zone (Pickford \& Morales, 1994). The latter hypothesis has recently received support from palaeoclimatic studies (Böhme et al., 2008) which indeed indicate that much of southern Europe enjoyed a monsoontype climate with hot, humid conditions for the period under consideration. Under the Pickford \& Morales (1994) hypothesis, there were considered to be strong biogeographic links from Euro-Africa to India and south-east Asia during the same period, in accordance with the subsequent findings of Böhme et al. (2008), an interesting point, given repeated interpretations that some European fossil apes were morphologically close to Asian ones. Reexamination of African, European and Asian late Miocene apes with this in mind, may reveal that one or other of the four or more lineages now commonly accepted to have occurred in Europe may share features with younger lineages in both Africa and Asia. If this is correct, then the European fossil record may well hold the key to understanding the origins of all extant apes.

\section{Conclusions}

Neuhausen, in the Swabian Alb, Germany, was among the first localities to yield fossil apes. Three teeth from the site collected in 1837 , were incorrectly identified as perissodactyls in 1839 (Jäger, 1839), two years after Lartet (1837) announced the discovery of the fossil that would eventually become known as Pliopithecus antiquus, and 17 years before Lartet (1856) described Dryopithecus fontani from St Gaudens, France. The illustrations published by Jäger in 1839 are excellent, and permit positive identification of the specimens. The fossils are curated at the State Museum of Natural History, Stuttgart, where they are stored with other material from the Bohnerz of the Swabian Alb, in the same cabinet as other ape fossils (and casts) from Ebingen, Melchingen, Salmendingen and Trochtelfingen. The three teeth from Neuhausen are described in detail for the first time, the original publications having concentrated on superficial preservation characteristics rather than details of morphology. The fossils are attributed to Dryopithecinae. The other faunal remains from Neuhausen with preservation characters similar to the dryopithecine teeth, indicate a Vallesian age (ca 9-11 Ma). The specimens are the first known antemolar teeth of Miocene hominoids from Germany, and they throw a great deal of light on the affinities of these apes. German Miocene hominoid teeth are here reinterpreted in light of new discoveries of fossil hominoids in Spain, which reveal a high diversity of hominoids in Europe at the end of the Middle Miocene (MN 7/8) and the beginning of the Upper Miocene (MN 9-10). This finding contrasts with the view that Europe possessed only one Miocene ape genus, Dryopithecus (Martin \& Andrews, 1993). 
The hominoids from Germany are most similar to those of Spain and they have weaker affinities to those from Austria, Slovakia, Hungary and Turkey. It is now clear that Miocene hominoid diversity in Germany was high (four species at least) and that the fauna had stronger biogeographic links to Spain than to Austria, Hungary, Slovakia and Turkey.

The dagger-like form and the dimensions of the upper canine from Neuhausen are close to those of Anoiapithecus brevirostris. The pillar-like morphology of the upper central incisor and the concave buccal surface of the upper third premolar, among other features, agree with the material from Can Ponsic, Spain, attributed to Dryopithecus crusafonti but they differ markedly from specimens attributed to Hispanopithecus laietanus (Begun, 1992a; Harrison, 1991; Moyà-Solà \& Köhler, 1995; Ribot et al., 1996) and Dryopithecus fontani (Moyà-Solà et al., 2009). They differ from the Rudabánya fossils attributed to Rudapithecus hungaricus (Begun \& Kordos, 1993, 1997; Kretzoi, 1969, 2002).

The three hominoid fossils from Neuhausen are likely the first dryopithecine teeth ever found, having been donated to the SMNS in 1837. The correct identification of these teeth, even though delayed for 170 years, places Germany among the countries of importance for understanding the evolution of Miocene hominoids, especially because the specimens are among the most septentrional in the world $\left(47^{\circ} 59^{\prime} \mathrm{N}\right.$ : $\left.8^{\circ} 53^{\prime} \mathrm{E}\right)$, only the specimens from the other Swabian Alb deposits and the material from Wissberg, near Gau-Weinheim in the Rhine Graben $\left(49^{\circ} 52^{\prime} \mathrm{N}\right.$ : $\left.7^{\circ} 59^{\prime} \mathrm{E}\right)$ being from further north (Fig. 1). The sedimentology of the Miocene Bohnerz indicates that the climate was probably tropical to sub-tropical at the time of deposition, in agreement with the presence of hominoids in southern Germany at the time, ca 10-9 Ma (Böhme et al., 2008). Further study of Bohnerz fossil assemblages would be of interest to undertake, especially for their palaeoclimatic implications.

The Neuhausen specimens, as an ensemble, are close morphometrically to specimens from Els Hostalets de Pierola and Can Ponsic, Spain. The fossil molars from other sites in the Swabian Alb show a diversity of dimensions and morphology, indicating a higher diversity of taxa than has generally been accepted for the past five decades. It is noted that a re-interpretation of the fossils in light of recent findings in Spain (Pie rolapithecus, Anoiapithecus, Hispanopithecus, and Dryopithecus) and Slovakia (Griphopithecus suessi) reveals that a comparably high diversity is present in the German collections. The possible presence of Griphopithecus sp. in Germany means that the Swabian Alb hominoids are potentially more diverse than those of Spain, where Griphopithecus-like teeth have not yet been recorded.

Neopithecus is a valid genus. What remains to be determined is its relationship to Anoiapithecus, Hispanopithecus, Udabnopithecus and Pierolapithecus

The species Neopithecus brancoi is valid, but its relationships to Sivapithecus occidentalis and Hispanopithecus laietanus (and by implications the nomen nudum Rahonapithecus sabadellensis) need to be established. Enamel thickness, dentine-enamel junction topography and root morphology studies would be informative in this respect.

Two teeth from La Grive St-Alban, France, traditionally identified as Dryopithecus fontani, are here attributed to Pierolapithecus catalaunicus.

What is not so clear is the status of the Rudabánya, Hungary, fossils. The presence of two upper central incisor morphotypes at the site suggests the presence of two taxa in the deposits, as originally proposed by Kretzoi (1969, 1974, 2002). The lower third premolar morphology differs from that of Dryopithecus, Pierolapithecus, Anoiapithecus and Hispanopithecus, but resembles that of Rudapithecus carinthiacus (comb. nov.), which should be recognised as a valid species. Whether the generic names Rudapithecus Kretzoi (1969) and Bodvapithecus Kretzoi (1975: the date given as 1974 by McKenna \& Bell 1997, appears to be an error) should be reinstated needs to be considered, in particular because Georgian Udabnopithecus predates both. Pending resolution of this problem, the Hungarian fossils are attributed to Rudapithecus carinthiacus.

On the basis of this study, the biogeographic affinities of the German dryopithecines seem to lie more strongly with Spain than with Austria, Slovakia and Hungary or Turkey, although the possible presence of Griphopithecus in Germany (Heizmann \& Begun, 2001) may provide a link to the eastern European and Turkish faunas.

It seems strange that the anterior teeth of hominoids from Germany (premolars, canines and incisors) should have escaped the notice of the researchers who studied the Swabian Alb collections (Branco 1898; Schlosser, 1901, 1902; and subsequent workers). One might well pose the question "How many other dryopithecine teeth are lying incorrectly identified in collections in the various institutions in Germany and elsewhere in Europe?" 
It is a testimony of the excellence of the successive curators at the SMNS that the entire collection from Neuhausen (as well as the original labels) has survived intact from the days that Jäger obtained them in 1837. The reinterpretation of the teeth described in this paper as those of dryopithecines, rather than perissodactyls, indicates that it is never a waste of time to browse through old, well-studied collections or to peruse ancient publications. It emphasises the importance of collections to palaeontology, and reveals that the current trend to relegate fossil collections to depots far from their parent museums may well be counterproductive for science.

\section{ACKNOWLEDGEMENTS}

I am anxious to thank Reinhard Ziegler and Elmar Heizmann at the SMNS for their hospitality and help in tracking down the old publications by Jäger and other authors. Thanks also to Madelaine Böhme and Manuela Aiglstorfer, Tübingen for help with archives and old publications. Thanks to the Collège de France, the Muséum National d'Histoire Naturelle, Paris, and the CNRS for support. Thanks also to Rob Kruszinski and Pip Brewer of the Natural History Museum, London, for access to hominoid fossils and casts in their care and Salvador MoyàSolà for the same at the Institut Català de Paleontologia, Barcelona. The paper was substantially improved following comments by the editor and two referees and Madelaine Böhme, who not only communicated the new catalogue numbers of the fossils housed in Tübingen, but also provided information concerning the Swabian Alb deposits and the decipherment of old hand-written labels.

\section{References}

Abel, O. (1902). Zwei fossilen Menschenaffen auf den Leithakalkbildungen des Wiener Beckens. Sitzungs berichten der Akademie der Wissenschaften in Wien, mathematisch-naturwissenshaftliche Klasse, 111: 1171-1207.

Abel, O. (1903). Zwei neue Menschenaffen aus den Leithakalkbildungen des Wiener Beckens. Centralblatt für Mineralogie, Geologie und Palaeontologie, 1903: 176182.

Abel, O. (1919). Das Entwicklungszentrum der Hominiden. Mitteilungen der Anthropologisches Gesellschaft, Wien, 49: 25-29.

Abel, O. (1931). Die Stellung des Menschen in Rahmen der Wirbeltiere. Gustav Fischer, Jena. 398 pp.

Alba, D.M.; Fortuny, J. \& Moyà-Solà, S. (2010). Enamel thickness in the middle Miocene great apes Anoiapithecus, Pierolapithecus, and Dryopithecus. Proceedings of the Royal Society, B. Biological Sciences. 1691: 2237-2245. doi:10.1098/rspb.2010.0218

Alpagut, B.; Andrews, P. \& Martin, L. (1990). New hominoid specimens from the Middle Miocene site at
Pasalar, Turkey. Journal of Human Evolution, 19: $397-$ 422. doi:10.1016/0047-2484(90)90052-D

Andrews, P.J. (1978). A revision of the Miocene Hominoidea of East Africa. Bulletin of the British Museum of Natural History, 30: 85-224. doi:10.1159/000155807

Andrews, P. \& Simons, E.L. (1977). A new African Miocene gibbon-like genus, Dendropithecus (Hominoidea: Primates) with distinctive postcranial adaptations: Its significance to origin of Hylobatidae. Folia Primatologica, 28: 161-168.

Andrews, P.; Harrison, T.; Delson, E.; Bernor, R. \& Martin, L. (1996). Distribution and biochronology of European and Southwestern Asian Miocene Catarrhines. In: The Evolution of Western Eurasian Neogene Mammal Faunas (Bernor, R. Fahlbusch, V. \& Mittmann H.-W., eds.). Columbia University Press, New York, 168-207.

Begun, D. (1989). A large Pliopithecine molar from Germany and some notes on the Pliopithecinae. Folia Primatologica, 52: 156-166. doi:10.1159/000156394

Begun, D. (1992a). Dryopithecus crusafonti sp. nov., a new Miocene hominoid species from Can Ponsic (northeastern Spain). American Journal of Physical Anthropology, 87: 291-309. doi:10.1002/ajpa.1330870306

Begun, D. (1992b). Phyletic diversity and locomotion in primitive European hominids. American Journal of Physical Anthropology, 87: 311-340. doi:10.1002/ ajpa. 1330870307

Begun, D. (2002). European hominoids, In: The Primate Fossil Record. (Hartwig, W.C., ed.) Cambridge University Press, Cambridge, 339-368.

Begun, D.; Ward, C.V, Deane, A.S.; Kivell, T.L.; Nargolwalla, M. \& Taylor, N.D. (2006). Stem hominine or hominid? The phylogeny and functional anatomy of Pierolapithecus catalaunicus. American Journal of Physical Anthropology, Supplement 42: 63.

Begun, D. (2009). Dryopithecins, Darwin, de Bonis, and the European origin of the African apes and human clade. Geodiversitas, 31: 789-816. doi:10.5252/ g2009n4a789

Begun, D. \& Kordos, L. (1993). Revision of Dryopithecus brancoi Schlosser, 1901, based on the fossil hominoid material from Rudabánya. Journal of Human Evolution, 25: 271-285. doi:10.1006/ jhev.1993.1049

Begun, D. \& Kordos, L. (1997). A new reconstruction of RUD 77, a partial cranium of Dryopithecus brancoi from Rudabánya, Hungary. American Journal of Physical Anthropology, 103: 277-294.

Begun, D. \& Ward, C. (2005). Comment on "Pierolapithecus catalaunicus, a new Middle Miocene great ape from Spain". Science, 308: 203c.

Böhme, M.; Ilg, A. \& Winklhofer, M. (2008). Late Miocene "Washhouse" climate in Europe. Earth and Planetary Science Letters, 275: 393-401.

Branco, W. (1898). Die menschenähnlichen Zähne aus dem Bohnerz der Schwäbischen Alb. Jahreshefte des Vereins für Vaterländische Naturkunde in Württemberg, Teil I, 54: 1-144.

Burtschak-Abramovitsch, N.O. \& Gabachvili, E.G. (1946). A superior anthropoid from the upper Tertiary 
deposits of Eastern Georgia (Kakhethia). Bulletin of the Museum of Georgia, 13: 255-273.

Burtschak-Abramovitsch, N.O. \& Gabachvili, E.G. (1950). Discovery of a fossil anthropoid in Georgia. Priroda, Leningrad, 9: 70-72.

Cameron, D. (1997). A revised systematic scheme for the Eurasian Miocene fossil Hominidae. Journal of Human Evolution, 33: 449-477. doi:10.1006/ jhev.1997.0145

Casanovas-Vilar, I.; Alba, D.; Moyà-Solà, S.; Galindo, J.; Cabrera, L.; Garcés, M.; Furio, M.; Robles, J.; Köhler, M. \& Angelone, C. (2008). Biochronological, taphonomical, and paleoenvironmental background of the fossil great ape Pierolapithecus catalaunicus (Primates, Hominidae). Journal of Human Evolution, 55: 589-603. doi:10.1016/j.jhevol.2008.05.004

Crusafont, M. (1958). Nuevo hallazgo del Pongido vallesiense Hispanopithecus. Boletin Informativo Acta Europea Paleontologia Vertebrados, 9: 13-14.

Crusafont, M. (1965). El desarrollo de los caninos en algunos driopitecidos des Vallesiense en Cataluña. Notas del Comision de investigationes geologicas y mineralogicas, 80: 179-192.

Crusafont, M. \& Golpe-Posse, J.-M. (1973). New pongids from the Miocene of Vallès-Penedès Basin (Catalonia, Spain). Journal of Human Evolution, 2: 17-23.

Crusafont, M. \& Hürzeler, J. (1961). Les pongidés fossiles d'Espagne. Comptes rendus de l'Académie des Sciences de Paris, 252: 582-584.

Crusafont, M. \& Hürzeler, J. (1969). Catálogo comentado de los póngidos fósiles de España. Acta Geológica Hispánica, 4: 44-48.

Crusafont, M. \& Truyols, L. (1954). Catálogo paleomastológico del Mioceno del Vallès-Penedès y de Calatayud-Teruel. Segundo Cursillo Internacional de Paleontologia, Sabadell: Museu de la Ciudad de Sabadell, Sección de Paleontología.

Depéret, C. (1911). Sur la découverte d'un grand singe anthropoide du genre Dryopithecus dans le Miocène moyen de La Grive St-Alban (Isère). Comptes rendus de l'Académie des Sciences de Paris, 153: 32-35.

Dubois, E. (1897). Über drei ausgestorbene Menschaffen. Neues Jahrbuch für Mineralogie, Geologie und Paläontologie, 1897: 83-104.

Ehrenberg, K. (1938). Austriacopithecus, ein neue menschenaffenartiger Primate aus dem Miozän von KleinHadersdorf bei Poysdorf in Niederösterreich (NiederDonau). Sitzungsberichten der Akademie der Wissenschaften in Wien, Mathematisch-naturwissenschaftlichen Klasse, 147: 71-110.

Gaudry, A. (1890). Le Dryopithèque. Mémoires de la Société géologique de France, 1: 1-11.

Glaessner, M. (1931). Neue Zähne von Menschenaffen aus dem Miozän des Wiener Beckens. Annalen der Naturhistorisches Museum, Wien, 46: 15-27.

Golpe-Posse, J.-M. (1982). Los Hispanopitecos (Primates, Pongidae) de los yacimientos del Vallès-Penedès (Cataluña, España). I. Material y a descrito. Butlletí Informatiu de l'Institut de Paleontologia de Sabadell, 14: 63-69.

Golpe-Posse, J.-M. (1982). Los Hispanopitecos (Primates, Pongidae) de los yacimientos del Vallès-Penedès
(Cataluña, España). II. Descripción del material existente en el Instituto de Paleontología de Sabadell. Paleontolgia y Evolució, 26-27: 151-224.

Gregory, W.K. (1916). Studies on the evolution of Primates. Bulletin of the American Museum of Natural History, 35: 336-344.

Gregory, W. \& Hellmann, M. (1926). The dentition of Dryopithecus and the origin of man. Anthropological Papers of the American Museum of Natural History. 28: $1-125$.

Gregory, W. \& Hellmann, M. (1939). The dentition of the extinct South African man-ape Australopithecus (Plesianthropus) transvaalensis Broom. A comparative and phylogenetic study. Annals of the Transvaal Museum, 19: 339-373.

Gregory, W.; Hellmann, M. \& Lewis, G. (1938). Fossil anthropoids of the Yale-Cambridge India Expedition of 1935. Publications of the Carnegie Institute Washington, 495: 1-27.

Harlé, E. (1898). Une machoire de Dryopithèque. Bulletin de la Société géologique de France, 26: 377-383.

Harlé, E. (1899). Nouvelles pièces de Dryopithèque et quelques coquilles, de Saint Gaudens. Bulletin de la Société géologique de France, 27: 304-310.

Haupt, O. (1935). Andere Wirbeltiere des Neozoikums. In: Salomon-Calvi, Öberrheinischer Fossilkatalog, Leifg. 4, 9: 1-103.

Heizmann, E. \& Begun, D. (2001). The oldest Eurasian hominoid. Journal of Human Evolution, 41: 463-481. doi:10.1006/jhev.2001.0495

Holec, P. \& Emry, R. (2003). Another molar of the Miocene hominid Griphopithecus suessi from the type locality at Sandberg, Slovakia. In: Vertebrate Fossils and their Context: Contributions in Honour of Richard H. Tedford. (Flynn, L.J., ed.) Bulletin of the American Museum of Natural History, 279: 625-631. Humphrey, L. \& Andrews, P. (2008). Metric variation in the postcanine teeth from Pasalar, Turkey. Journal of Human Evolution, 54: 503-517. doi:10.1016/j.jhevol.2007.08.002

Hürzeler, J. (1951). Contribution à l'étude de la dentition de lait d'Oreopithecus bambolii Gervais. Eclogae geologicae Helvetiae, 44: 404-411.

Hürzeler, J. (1954). Contribution à l'odontologie et à la phylogénèse du genre Pliopithecus Gervais. Annales de Paléontologie, 490: 1-63.

Jäger, G.F. (1835). Übersicht der fossilen Säugethiere, welche in Württemberg in verschiedenen Formationen aufgefunden worden sind. Carl Erhard, Stuttgart, pp. 170, Pl. I-IX.

Jäger, G.F. (1839). Über die fossilen Säugethiere, welche in Württemberg verschiedenen Formationen aufgefunden worden sind, nebst geognostischen Bemerkungen über diese Formationen. Carl Erhard, Stuttgart, pp. 71212, Pl. X-XX.

Jäger, G.F. (1850). Übersicht der fossilen Säugethiere, welche in Württemberg in verschiedenen Formationen aufgefunden worden sind, und nähere Beschreibung und Abbildung Einzelner derselben. Nova Acta Academiae Leopoldino-Carolinae Germanicae Naturae Curiosorum, 22: 765-924. 
Kelley, J. (2002). The hominoid radiation in Asia. In: The Primate Fossil Record. (Hartwig, W.C., Ed.) Cambridge University Press, Cambridge, 369-384.

Kelley, J.; Andrews, P. \& Alpagut, B. (2008). A new hominoid species from the middle Miocene site of Pasalar, Turkey. Journal of Human Evolution, 54: 455479. doi:10.1016/j.jhevol.2007.08.007

Köhler, M.; Moyà-Solà, S. \& Alba, D. (2001). Cranial reconstruction of Dryopithecus. American Journal of Physical Anthropology, 115: 284-288.

Köhler, M.; Moyà-Solà, S.; Alba, D. \& MacLatchy, L. (2002). Taxonomic affinities of the Eppelsheim femur. American Journal of Physical Anthropology, 119: 298304.

Koken, W. (1905). Führer durch die Sammlungen des Geologisches-Mineralogischen Instituts in Tübingen. Stuttgart, pp. 1-110.

Kordos, L. (1991). Le Rudapithecus hungaricus de Rudabánya (Hongrie). L'Anthropologie, 95: 343362. Kordos, L. \& Begun, D. (2001). A new cranium of Dryopithecus from Rudabánya, Hungary. Journal of Human Evolution, 41: 689-700. doi:10.1006/jhev.2001.0523

Kretzoi, M. (1969). Geschichte der Primaten und der hominisation. Symposium Biologicae hungaricae, 9: 3-11.

Kretzoi, M. (1975). New ramapithecines and Pliopithecus from the lower Pliocene of Rudabánya in northeastern Hungary. Nature, 257: 578-581. doi:10.1038/ $257578 \mathrm{a} 0$

Kretzoi, M. (2002). The Fossil Hominoids of Rudabánya (Northeastern Hungary) and the Early Hominization. Hungarian National Museum, Budapest, 287 pp.

Lapouge, G. (1894). Note sur un nouveau singe pliocène (Anthropodus rouvillei). Bullétin de la Société de Science médicale de l'Ouest, 3: 202-208.

Lartet, E. (1837). Note sur les ossements fossiles des terrains tertiaires de Simorre, de Sansan, etc., dans le département du Gers, et sur la découverte récente d'une machoire de singe fossile. Annales des Sciences naturelles, 13: 116-123.

Lartet, E. (1856). Note sur un grand singe fossile qui sera rattaché au groupe des singes supérieurs. Comptes rendus de l'Académie des Sciences de Paris, 43: 219-223.

Leakey, L.S.B. (1962). A new lower Pliocene fossil primate from Kenya. Annals and Magazine of Natural History, 13 (4): 689-697.

Le Gros Clark, W.E. \& Leakey, L.S.B. (1951). Miocene Hominoidea of East Africa. Fossil Mammals of Africa, 1: $1-117$.

Martin, L. \& Andrews, P. (1993). Renaissance of Europe's ape. Nature, 365: 494. doi:10.1038/364494a0

Mein, P. (1986). Chronological succession of hominoids in the European Neogene. In: Primate Evolution, (Else, J.G. \& Lee, P.C., eds.) Volume 1, Cambridge University Press, Cambridge, 59-70.

Mottl, M. (1957). Bericht über die neuen Menschenaffenfunde aus Österreich, von St Stefan im Levanttal, Kärnten: Carinthia 2. Mitteilungen des Naturwissenschaftlichen vereins in Kärnten, 67: 39-84.
Moyà-Solà, S. \& Köhler, M. (1993). Recent discoveries of Dryopithecus shed new light on evolution of great apes. Nature, 365: 543-545.

Moyà-Solà, S. \& Köhler, M. (1995). New partial cranium of Dryopithecus Lartet, 1863 (sic) (Hominoidea, Primates) from the upper Miocene of Can Llobateres, Barcelona, Spain. Journal of Human Evolution, 29: 101-139.

Moyà-Solà, S. \& Köhler, M. (1996). A Dryopithecus skeleton and the origins of great-ape locomotion. Nature, 379: 156-159.

Moyà-Solà, S.; Köhler, M.; Alba, D.; Casanovas-Vilar, I. \& Galindo, J. (2004). Pierolapithecus catalaunicus, a new Middle Miocene great ape from Spain. Science, 306: 1339-1344.

Moyà-Solà, S.; Köhler, M.; Alba, D.; Casanovas-Vilar, I.; Galindo, J.; Robles, J.; Cabrera, L.; Garcés, M.; Almécija, S. \& Beamud, E. (2009a). First partial face and upper dentition of the Middle Miocene hominoid Dryopithecus fontani from Abocador de Can Mata (Vallès-Penedès Basin, Catalonia, NE Spain): Taxonomic and phylogenetic implications. American Journal of Physical Anthropology, 139: 126-145.

Moyà-Solà, Alba, D.; Almécija, S.; Casanovas-Vilar, I.; Köhler, M.; Esteban-Trivigno, S.; Robles, J.; Galindo, J. \& Fortuny, J. (2009b). A unique Middle Miocene European hominoid and the origins of the great ape and human clade. Proceedings of the National Academy of Sciences, 106: 9601-9606.

Pickford, M. (1985). A new look at Kenyapithecus based on recent collections from Western Kenya. Journal of Human Evolution, 14: 113-143. doi:10.1016/S00472484(85)80002-6

Pickford, M. \& Chiarelli, A.B. (1986). Sexual Dimorphism in Living and Fossil Primates. Il Sedicesimo, Firenze, 215 pp.

Pickford, M. \& Morales, J. (1994). Biostratigraphy and palaeobiogeography of East Africa and the Iberian Peninsula. Palaeogeography, Palaeoclimatolology, Palaeoecology, 112: 297-322. doi:10.1016/00310182(94)90078-7

Pickford, M.; Musalizi, S.; Senut, B.; Gommery, D. \& Musiime, E. (2010). Small apes from the Early Miocene of Napak, Uganda. Geo-Pal Uganda, 3: 1-111.

Pickford, M. \& Senut, B. (2005). Hominoid teeth with chimpanzee and gorilla-like features from the Miocene of Kenya: Implications for the chronology of the apehuman divergence and biogeography of Miocene hominoids. Anthropological Science, 113: 95-102. doi:10.1537/ase.04S014

Pohlig, H. (1895). Paidopithex rhenanus n. g., n. sp., le singe anthropomorphe du Pliocène rhénan. Bulletin de la Société belge de Géologie, 9: 149-151.

Quenstedt, F.A. von, (1853). Handbuch der Petrefactenkunde. Tübingen, 1239 pp.

Remane, A. (1921a). Zur Beurteilung der fossilen Anthropoiden. Centralblatte für Mineralogie etc., 11: 335-339.

Remane, A. (1921b). Beiträge zur Morphologie des Anthropoidengebisses. Archive für Naturgeschichte, 87: 1-179. 
Ribot, F.; Gibert, J. \& Harrison, T. (1996). A reinterpretation of the taxonomy of Dryopithecus from VallèsPenedès, Catalonia (Spain). Journal of Human Evolution, 31: 129-141. doi:10.1006/jhev.1996.0054

Schlosser, M. (1888). Die Affen, Lemuren, Chiropteren etc., des europäischen Tertiärs. Beitrage der Paläontologie und Geologie Österreiche-Ungarns, 6: 1-224.

Schlosser, M. (1901). Die menschenähnlichen Zähne aus dem Bohnerz der schwäbischen Alb. Zoologischer Anzeiger, 24: 261-271.

Schlosser, M. (1902). Beiträge zur Kenntniss der Säugethierreste aus den süddeutschen Bohnerzen. Geologische und Palaeontologische Abhandlungen, 3: 117-258.

Simons, E.L. \& Pilbeam, D.R. (1965). Preliminary revision of the Dryopithecinae (Pongidae, Anthropoidea). Folia Primatologica, 3: 81-152. doi:10.1159/000155026

Simons, E.L. \& Pilbeam, D.R. (1978a). Cenozoic apes. In: Evolution of African Mammals. (Maglio, V.J. \& Cooke, H.B.S., eds.) Harvard University Press, Boston, 120-146.

Simons, E.L. \& Pilbeam, D.R. (1978b). Ramapithecus (Hominidae, Hominoidea). In: Evolution of African Mammals. (Maglio, V.J. \& Cooke, H.B.S., eds.) Harvard University Press, Boston, 147-153.

Steininger, F. (1986). Dating the Paratethys Miocene hominoid record. In: Primate Evolution, (Else, J.G. \& Lee, P.C., eds.) Volume 1, Cambridge University Press, Cambridge, 71-84.

Steininger, F. \& Thenius, E. (1963a). Ein neuer Pongidenfund aus dem Miozän des Wiener Beckens. Anthropologischer Anzeiger, 26: 211-215.

Steininger, F. \& Thenius, E. (1963b). Zum ältesten Vorkommen fossiler Menschenaffen (Fam. Pongidae) in Europa. Sitzung der Mathematisch-naturwissenschaftlichen Klasse. 2: 1-8.

Szalay, F. \& Delson, E. (1979). Evolutionary History of the Primates. Academic Press, London, $580 \mathrm{pp}$.

Tekkaya, I. (1974). A new species of Tortonian Anthropoid (Primates, Mammalia) from Anatolia. Bulletin of the Mineral Research and Exploration Institute of Turkey, 83: 148-164.
Thenius, E. (1982). Ein Menschenaffen (Primates: Pongidae) aus dem Pannon (Jung-Miozän) von Niederösterreich. Folia Primatologica, 39: 187-200. doi: 10.1159/000156077

Van der Made, J. \& Ribot, F. (1999). Additional hominoid material from the Miocene of Spain and remarks on hominoid dispersals into Europe. Contributions to Tertiary and Quaternary Geology, 36: 25-39.

Vidal, L.M. (1913). Nota sobre la presencia del «Dryopithecus» en el Mioceno superior del Pirineo catalan. Boletin de la Real Sociedad española de Historia natural, 13: 499-507.

Villalta, J. \& Crusafont, M. (1941). Hallazgo del «Dryopithecus fontani» Lartet, en el Vindoboniense de la cuenca Vallès-Penedès. Boletín del Instituto Geológico y Minero de España, 20: 3-15.

Villalta, J. \& Crusafont, M. (1944). Dos nuevos antropomorfos del Mioceno español y su situación dentro de la moderna sistemática de los símidos. Notas y Comunicaciones del Instituto Geológico y Minero de España, 13: 91-139.

Von Koenigswald, G. (1956a). Gebissreste von Menschenaffen aus dem Unter-Pliozän Rheinhessens.

Von Koenigswald, G. (1956b). Gebissreste von Menschenaffen aus dem Unter-Pliozän Rheinhessens. II. Koninklijke Nederlandse Akademie van Wetensschappen, B 59: 330-334.

Woodward, A.S. (1914). On the lower jaw of an anthropoid ape (Dryopithecus) from the Upper Miocene of Lérida (Spain). Quarterly Journal of the Geological Society of London, 70: 316-320.

Zapfe, H. (1989). Pongidenzähne (Primates) aus dem Pontien von Götzendorf, Niederösterreich. Sitzungsberichten der Österreichische Akademie der Wissenschaften mathematisch-naturwissenschaftliche Klasse, 197: 423-450.

Recibido el 24 de mayo de 2010 Aceptado el 10 de noviembre de 2010 Publicado online el 5 de octubre de 2011 